\title{
Energy evaluation of R152a as drop in replacement for R134a in cascade refrigeration plants.
}

\author{
R. Cabello ${ }^{a^{*}}$, D. Sánchez ${ }^{a}$, R. Llopis ${ }^{a}$, J. Catalán $^{a}$, L. Nebot-Andrés $^{a}$, E. Torrella ${ }^{b}$ \\ aUniversitat Jaume I, Dep. of Mechanical Engineering and Construction, Campus de Riu Sec s/n \\ E-12071, Castellón, Spain \\ bUniversitat Politècnica de València, Department of Applied Thermodynamics, Camino de Vera, 14, \\ E-46022, Valencia, Spain
}

*Corresponding author: R. Cabello (cabello@uji.es), Phone: +34 96472 8135; Fax: +34 964728106.

\section{ABSTRACT}

An experimental comparison has been performed of a cascade refrigeration facility working with therefrigerant pairs R134a/R744 and R152a/R744. This kind of facility is suitable for industrial and commercial refrigeration applications. The high GWP refrigerant R134a has been substituted with the low GWP refrigerant R152a, in accordance with the new environmental regulations aimed at mitigating the Greenhouse effect. As both refrigerants belong to the family of HFC fluids, the replacement has been carried out as a drop-in. Apart from safety considerations, as R152a is included in the A2 group, the results of the wide range of tests conducted show that no special energy improvement or worsening is achieved, and that the replacement of R134a with R152a is technically and energetically feasible.

\section{KEYWORDS}

$\mathrm{R} 152 \mathrm{a}, \mathrm{R} 134 \mathrm{a}, \mathrm{CO}_{2}$, Low GWP refrigerants, Cascade refrigeration system. 
COP

$c_{p}$

GWP

$h$

$\mathrm{HOC}$

HTC

LTC

MW

$\dot{\mathrm{m}}$

N

NBP

p

$P_{C}$

$\dot{Q}$

$q_{0}$

$q_{v}$

SF

$t$

$T$

V

$\dot{V}$

$\dot{V}_{\mathrm{G}}$

$W_{c}$

$w_{C S}$

$x_{v}$ coefficient of performance

specific isobaric heat, $\mathrm{kJ} \cdot \mathrm{kg}^{-1} \cdot \mathrm{K}^{-1}$

global warming potential (100 years integration)

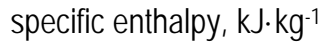

Heat of combustion

high temperature cycle

low temperature cycle

Molecular weight $\mathrm{kg} \cdot \mathrm{kmol}^{-1}$

mass flow rate, $\mathrm{kg} \cdot \mathrm{s}^{-1}$

Compressor speed (r.p.m.)

Normal boiling point

pressure, bar

compressor power consumption, kW

heat transfer rate, $\mathrm{kW}$

Specific cooling capacity $(\mathrm{kJ} / \mathrm{kg})$

Volumetric refrigerating effect $\left(\mathrm{kJ} / \mathrm{m}^{3}\right)$

secondary fluid

pressure ratio

temperature, ${ }^{\circ} \mathrm{C}$

specific volume, $\mathrm{m}^{3} \cdot \mathrm{kg}^{-1}$

Volumetric flow rate, $\mathrm{m}^{3} \cdot \mathrm{h}^{-1}$

Compressor displacement, $\mathrm{m}^{3} \cdot \mathrm{s}^{-1}$

specific compression work, $\mathrm{kJ} \cdot \mathrm{kg}^{-1}$

isentropic specific compression work, $\mathrm{kJ}^{\cdot \mathrm{kg}^{-1}}$

vapor quality

\section{GREEK SYMBOLS}

$\Delta$

$\lambda$

$\eta_{G}$

$\eta_{s}$

$\eta_{v}$

\section{Increment}

latent heat $(\mathrm{kJ} / \mathrm{kg})$

compressor global efficiency

compressor isentropic efficiency

compressor volumetric efficiency 
$\rho \quad$ density, $\mathrm{kg} \cdot \mathrm{m}^{-3}$

SUBSCRIPTS

$\begin{array}{cl}\text { casc } & \text { Cascade } \\ \text { crit } & \text { critical } \\ \text { dis } & \text { Discharge } \\ \text { env } & \text { environment } \\ H & \text { high-temperature cycle } \\ k & \text { condensing level } \\ L & \text { low-temperature cycle } \\ o & \text { evaporating level } \\ r e f & \text { Refrigerant } \\ s & \text { Isentropic } \\ \text { sf } & \text { Secondary fluid } \\ \text { suc } & \text { Suction }\end{array}$




\section{Introduction}

Guided by UNEP and IPCC reports, a global warming limit of $2{ }^{\circ} \mathrm{C}$ or below (relative to pre-industrial levels) has been adopted as a threshold for mitigation efforts targeted toward reducing climate change risks, impacts and damage [IPCC (2014); European Commission (2005); M. Meinshausen et al. (2009)].

Accordingly, new regulations regarding fluorinated gases (F-Gases) are being approved, with the aim of achieving a reduction in the use and commercial availability of this kind of gases when their GWP present a high value. A clear example is Regulation EU n0 517/2014 [European Commission (2014)] passed in the European Union. This Regulation establishes, among other restrictions, a 79\% reduction in the amount of hydrofluorocarbons to be placed on the market by the year 2030 with respect to the annual average of the total amount placed on the market in the Union during the period from 2009 to 2012. Moreover, in European countries like Spain, new laws have come into force that impose taxes on the F-Gases with GWP values higher than 150 [Law (2013); RD (2013)].

Section 13 of Annex II of Regulation EU no 517/2014 imposes a ban on placing multipack centralized refrigeration systems on the market for commercial use if they have a rated capacity of $40 \mathrm{~kW}$ or more and contain, or whose functioning relies upon, fluorinated greenhouse gases with a GWP of 150 or more. An exception to this ruling is in the primary refrigerant circuit of cascade systems, where fluorinated greenhouse gases with a GWP below 1500 may be used.

Nowadays, the refrigeration systems mounted for commercial applications normally use the working fluids R134a, R404A and R507A in direct expansion systems [Kauffeld (2008), Arora and Kaushik (2008)]. Their GWP values are 1300, 3943 and 3985 respectively, as published in the Assessment Report 5 of the Working Group I [IPCC (2013)], which means that those refrigeration systems must be either retrofitted or replaced with new ones adapted to the refrigerants allowed by Regulation EU no 517/2014 (HFC with low GWP, HFOs, Hydrocarbons, $\mathrm{CO}_{2}$ and ammonia) [M. Mohanraj et al. (2009); AREA (2011); W. Goetzler et. Al. (2014); JM. Calm (2008)].

The refrigeration technologies for commercial applications, with medium and high cooling capacity demands, that best suit the refrigerants allowed by the Regulation mentioned above are the following multi-stage vapor compression ones: Transcritical $\mathrm{CO}_{2}$ booster system with direct expansion, direct cascade and indirect cascade. Both cascade types uses subcritical $\mathrm{CO}_{2}$ in direct expansion for low temperature, but the direct one works in direct expansion for medium temperature and the indirect one works with a secondary fluid for medium temperature [O. Abdelaziz (2012); Vishaldeep et al. (2014); M. Beshr et al. (2015), R. Llopis et al. $(2015, a)]$. 
The present paper is focused on the experimental comparison of a direct cascade refrigeration plant working with the refrigerant pairs R134a/R744 and R152a/R744 under a wide range of operating conditions. The results are a valuable contribution to the experimental knowledge on this kind of refrigeration plants, especially because no data with R152a can be found in the literature. R152a is a low GWP refrigerant, with a reduced price compared to other HFC and HFO refrigerants, and is included in the A2 safety group following the ASHRAE Std32 [ASHRAE (2013)] designation. The results revealed the technological feasibility of using R152a as a replacement fluid for R134a, without any detrimental effect on the energy performance of the plant. Safety considerations are not within the scope of this work.

\section{Refrigerant Comparison}

The basic properties of R152a and R134a are shown in Table 1. The data shown in this table are taken from a paper published by R. Cabello et al. (2015), where different aspects of these two refrigerants are discussed. Thermodynamic properties are calculated using the software application REFPROP v9.1 [Lemmon et al. (2013)], the Safety Group is in accordance with ASHRAE Std-34 [ASHRAE (2013)], HOC and RCL values are extracted from [Calm (2012)], and GWP values are taken from [IPCC (2013)].

\begin{tabular}{|c|c|c|c|c|c|c|c|c|c|c|c|c|}
\hline Fluid & $\begin{array}{c}\text { Chemical } \\
\text { formula }\end{array}$ & $\begin{array}{l}\mathrm{P}_{\text {crit }} \\
(\mathrm{MPa}) \\
\end{array}$ & $\begin{array}{l}\text { crit } \\
\left({ }^{\circ} \mathrm{C}\right) \\
\end{array}$ & $\begin{array}{c}\mathrm{MW} \\
\left(\mathrm{kg} \cdot \mathrm{kmol}^{-1}\right) \\
\end{array}$ & $\begin{array}{l}\text { NBP } \\
\left({ }^{\circ} \mathrm{C}\right) \\
\end{array}$ & $\frac{V_{\text {sat, }, *}^{*}}{\left(m^{3} \cdot \mathrm{kg}^{-1}\right)}$ & $\frac{\lambda^{*}}{\left(\mathrm{~kJ} \cdot \mathrm{kg}^{-1}\right)}$ & $\frac{q v^{*}}{\left(k J \cdot m^{-3}\right)}$ & $\begin{array}{l}\text { Safety } \\
\text { Group } \\
\end{array}$ & $\frac{\mathrm{RCL}}{\left(\mathrm{gr} \cdot \mathrm{m}^{-3}\right)}$ & $\begin{array}{c}\text { HOC } \\
\left(\mathrm{MJ}^{\prime} \mathrm{kg}^{-1}\right) \\
\end{array}$ & $\begin{array}{c}\text { GWP1 }^{1} \\
\text { WGI-AR5 }^{1} \\
\end{array}$ \\
\hline R152a & $\mathrm{CH}_{3} \mathrm{CHF}_{2}$ & 4.52 & 113.26 & 66.051 & -24.02 & 0.296 & 329.91 & 1113.66 & A2 & 32 & 17,4 & 138 \\
\hline R134a & $\mathrm{CH}_{2} \mathrm{FCF}_{3}$ & 4.06 & 101.06 & 102.032 & -26.07 & 0.190 & 216.97 & 1140.81 & A1 & 210 & 4.2 & 1300 \\
\hline
\end{tabular}

Table 1 - Main thermodynamic, safety and environmental properties of R134a and R152a

Both refrigerants are HFC, but the first issue to comment on is the GWP value of R152a, which is below 150. This means that R152a is beyond the scope of the new regulations related to F-Gases, so no reductions, replacements, prohibitions or taxes should be applied to this fluid. This is not the case of R134a, which has a higher GWP (1300) and the new F-Gas regulations apply.

The molecules of R134a and R152a are derived from the ethane molecule, and consist of the same type of atoms (hydrogen, carbon and fluorine) and the same kind of bonds between them, so the material and lubricant compatibility is the same for both refrigerants. Therefore, R152a could be a drop-in replacement for R134a. However, the increased presence of hydrogen atoms at the expense of fluorine atoms in the R152a molecule with respect to that of R134a is the main drawback of R152a compared with R134a, because it generates a higher flammability, to the extent that R152a meets ASHRAE Std 34 criteria for A2 status.

Both refrigerants present a similar NBP and critical point and therefore both can be used in the same temperature range. Notwithstanding, the latent heat and specific volume of R152a are much greater than R134a. 
On the one hand, the higher latent heat of R152a than that of R134a will imply that its mass flow rate will be smaller to obtain the same cooling duty, which will have a bearing on lesser compressor power consumption. On the other hand, the higher specific volume of R152a with respect to R134a will mean that less refrigerant mass will need to be charged in the facility in order to reach the same saturation temperatures. The result of dividing the latent heat between the specific volume, named volumetric refrigerating effect $\left(q_{v}\right)$, yields values that are 10\%y greater for R134a than for R152a, which means that the compressor dimensioned for R134a will be slightly smaller for R152a if the same cooling duty is to be obtained.

\section{Cascade Theoretical study}

First we present an approximate theoretical study of a cascade cycle working with the refrigerant pairs R134a/R744 and R152a/R744, in order to check the discrepancies, if any, between the theoretical and the actual behavior of a cascade refrigeration cycle. The starting data to calculate the cycle are given in Table 2.

\begin{tabular}{|c|c|c|}
\hline & $\begin{array}{l}\text { High Temperature Cycle } \\
\text { (HTC) }\end{array}$ & $\begin{array}{c}\text { Low Temperature Cycle } \\
\text { (LTC) }\end{array}$ \\
\hline \multirow{2}{*}{ Working Fluid } & HFC134a & \multirow{2}{*}{$\mathrm{R} 744\left(\mathrm{CO}_{2}\right)$} \\
\hline & HFC152a & \\
\hline Evaporating Temperature $\left({ }^{\circ} \mathrm{C}\right)$ & - & $T_{O L}=-30$ \\
\hline Condensing temperature $\left({ }^{\circ} \mathrm{C}\right)$ & $T_{k H}=30$ & $T_{k L}=-7$ \\
\hline Superheat at evaporator outlet $(K)$ & 5 & 5 \\
\hline Subcooling at expansion valve inlet $(K)$ & 2 & 2 \\
\hline Superheat at compressor suction (K) & 15 & 15 \\
\hline Isentropic efficiency* & $\eta_{s}=1-0,02 \cdot \frac{p_{k}, H}{p_{O, H}}$ & $\eta_{s}=1-0,04 \cdot \frac{p_{k}, L}{p_{O, L}}$ \\
\hline Volumetric efficiency* & $\eta_{v}=1-0,02 \cdot \frac{p_{k}, H}{p_{O, H}}$ & $\eta_{v}=1-0,04 \cdot \frac{p_{k}, L}{p_{O, L}}$ \\
\hline Refrigeration load $\left(\dot{Q}_{O, L}, k W\right)$ & & \\
\hline$\Delta \mathrm{T}_{\text {casc. }}(\mathrm{K})$ & & \\
\hline
\end{tabular}

Table 2. Input data for theoretical simulation.

*These linear correlations of the compressor efficiencies with the pressure ratio are taken from the literature, for instance W.B.Gosney 1982 and E. Granryd 2009. Meanwhile, the particular coefficients and constants used in the correlations are taken from author's experience. 
The value of the LTC parameters are equal regardless of the refrigerant considered in HTC, which means there will be the same evaporation temperature at the $H T$ and the same $\Delta T_{\text {casc }}$. for both refrigerants. Thermodynamic properties have been calculated by means of the software application REFPROPv9.1 [Lemmon et al. (2013)]. The corresponding R134a/R744 and R152a/R744 cycles are shown in Figure 1, where LTC is depicted in a vanished gray color, and HTC for R134a and R152a are depicted in red and green respectively.

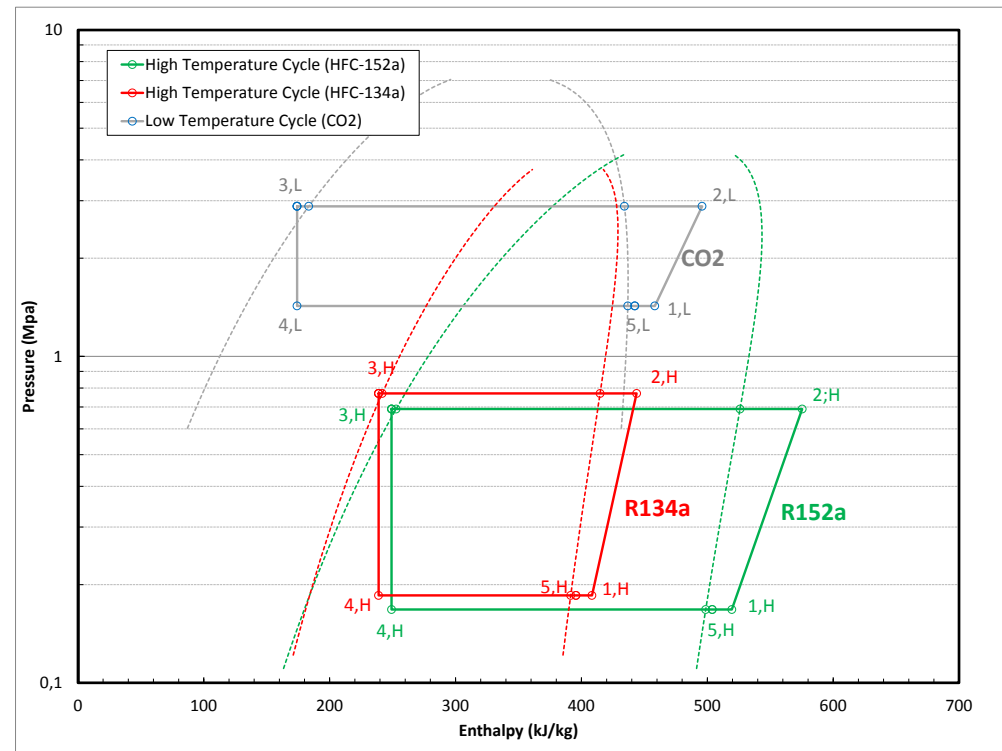

Figure 1. Comparison of the theoretical cascade cycles for R134a/R744 and R152a/R744.

Once the thermodynamic properties have been calculated, the main energy parameters are obtained using the set of equations shown in Table 3 . There is a correspondence between subscripts in the equations and those in the cycles depicted in Figure 1. The results of the energy parameters calculated are shown in Table 4.

\begin{tabular}{c|c|c|c}
\hline$q_{o}=h_{5}-h_{4}$ & Eq (1) & $q_{v}=\frac{q_{o}}{v_{1}}$ & Eq (2) \\
\hline$\dot{m}_{r e f, L}=\frac{\dot{Q}_{o, L}}{q_{o, L}}$ & Eq (3) & $\dot{m}_{r e f, H}=\frac{\dot{m}_{r e f, L} \cdot\left(h_{2 L}-h_{3 L}\right)}{q_{o, H}}$ & Eq (4) \\
\hline$\dot{V}_{G}=\frac{\dot{m}_{r e f} \cdot v_{1}}{\eta_{v}}$ & Eq (5) & $w_{c, s}=h_{2 s}-h_{1}$ & Eq (6) \\
\hline$w_{c}=\frac{h_{2 s}-h_{1}}{\eta_{i}}$ & Eq (7) & $P_{C}=\dot{m}_{r e f} \cdot w_{c}$ & Eq (8) \\
\hline$t=\frac{p_{k}}{p_{o}}$ & Eq (9) & $C O P_{L}=\frac{h_{5 L}-h_{4 L}}{h_{2 L}-h_{1 L}}$ & Eq \\
\hline$C O P_{H}=\frac{h_{5 H}-h_{4 H}}{h_{2 H}-h_{1 H}}$ & Eq (11) & $=\frac{\operatorname{COP}_{c a s c .}=}{\dot{m}_{r e f, L} \cdot\left(h_{5 L}-h_{4 L}\right)}$ & Eq \\
\hline
\end{tabular}


Table 3. Equations used in the theoretical simulation.

\begin{tabular}{|c|c|c|c|c|c|}
\hline \multicolumn{3}{|c|}{ HTC results with R152a } & \multicolumn{3}{|c|}{ HTC results with $\mathrm{R} 134 a$} \\
\hline$\dot{m}_{r e f, H}$ & $(\mathrm{~kg} / \mathrm{s})$ & 0.0047 & $\dot{m}_{r e f, H}$ & $(\mathrm{~kg} / \mathrm{s})$ & 0.0076 \\
\hline$q_{0, H}$ & $(\mathrm{~kJ} / \mathrm{kg})$ & 254.7 & $q_{0, H}$ & $(\mathrm{~kJ} / \mathrm{kg})$ & 156.8 \\
\hline$q_{v, H}$ & $\left(\mathrm{~kJ} / \mathrm{m}^{3}\right)$ & 1264.4 & $q_{v, H}$ & $\left(\mathrm{~kJ} / \mathrm{m}^{3}\right)$ & 1331,8 \\
\hline$\dot{V}_{G, H}$ & $\left(\mathrm{~m}^{3} / \mathrm{s}\right)$ & 0.00103 & $\dot{V}_{G, H}$ & $\left(\mathrm{~m}^{3} / \mathrm{s}\right)$ & 0.00098 \\
\hline$W_{c, s, H}$ & $(\mathrm{~kJ} / \mathrm{kg})$ & 51.3 & $W_{\mathrm{c}, \mathrm{S}, \mathrm{H}}$ & $(\mathrm{kJ} / \mathrm{kg})$ & 32.6 \\
\hline$W_{c, H}$ & $(\mathrm{~kJ} / \mathrm{kg})$ & 55.9 & $W_{c, H}$ & $(\mathrm{~kJ} / \mathrm{kg})$ & 35.5 \\
\hline $\mathrm{PC}, \mathrm{H}$ & $(\mathrm{W})$ & 263 & $\mathrm{PC}, \mathrm{H}$ & $(\mathrm{W})$ & 271 \\
\hline$T_{\text {dis }, H}$ & $\left(\mathrm{~K} /{ }^{\circ} \mathrm{C}\right)$ & $342.3 / 69.2$ & $T_{\text {dis }, H}$ & $\left(\mathrm{~K} /{ }^{\circ} \mathrm{C}\right)$ & $316.0 / 42.9$ \\
\hline$t_{H}$ & - & 4.11 & $t_{H}$ & - & 4.15 \\
\hline $\mathrm{COP}_{\mathrm{H}}$ & - & 3.6 & $\mathrm{COP}_{\mathrm{H}}$ & - & 3.3 \\
\hline \multicolumn{6}{|c|}{ LTC results with R744 } \\
\hline \multicolumn{2}{|c|}{$\dot{m}_{r e f, L}$} & \multicolumn{2}{|c|}{$(\mathrm{kg} / \mathrm{s})$} & \multicolumn{2}{|c|}{0.0037} \\
\hline \multicolumn{2}{|c|}{$q_{0, L}$} & \multicolumn{2}{|c|}{$(\mathrm{kJ} / \mathrm{kg})$} & \multicolumn{2}{|c|}{268.3} \\
\hline \multicolumn{2}{|c|}{$q_{v, L}$} & \multicolumn{2}{|c|}{$\left(\mathrm{kJ} / \mathrm{m}^{3}\right)$} & \multicolumn{2}{|c|}{8738.9} \\
\hline \multicolumn{2}{|c|}{$\dot{V}_{G, L}$} & \multicolumn{2}{|c|}{$\left(\mathrm{m}^{3} / \mathrm{s}\right)$} & \multicolumn{2}{|c|}{0.00012} \\
\hline \multicolumn{2}{|c|}{$W_{c, S, L}$} & \multicolumn{2}{|c|}{$(\mathrm{kJ} / \mathrm{kg})$} & \multicolumn{2}{|c|}{33.3} \\
\hline \multicolumn{2}{|c|}{$W_{c, L}$} & \multicolumn{2}{|c|}{$(\mathrm{kJ} / \mathrm{kg})$} & \multicolumn{2}{|c|}{37.6} \\
\hline \multicolumn{2}{|c|}{$\mathrm{PC}, \mathrm{L}$} & \multicolumn{2}{|c|}{$(W)$} & \multicolumn{2}{|c|}{140} \\
\hline \multicolumn{2}{|c|}{$T_{\text {dis }, L}$} & \multicolumn{2}{|c|}{$\left(\mathrm{K} /{ }^{\circ} \mathrm{C}\right)$} & \multicolumn{2}{|c|}{$316.6 / 42.9$} \\
\hline \multicolumn{2}{|c|}{$t_{L}$} & \multicolumn{2}{|c|}{-} & \multicolumn{2}{|c|}{2.40} \\
\hline \multicolumn{2}{|c|}{$\mathrm{COP}$} & \multicolumn{2}{|c|}{-} & \multicolumn{2}{|c|}{5.0} \\
\hline $\mathrm{COP}_{\text {casc }}$ & $\left.\mathrm{R} 152 \mathrm{a} / \mathrm{CO}_{2}\right)$ & 2.480 & $\mathrm{COP}_{\text {casc }}$ & (R134a/C & 2.430 \\
\hline
\end{tabular}

Table 4. Energy parameters calculated.

Focusing on the HTC results shown in Table 4 , the specific cooling capacity $\left(q_{0}\right)$ is much greater for R152a than for R134a, which results in a substantial reduction in the mass flow rate for the same cooling duty. Notwithstanding, this reduction in mass flow rate does not lead to a reduction in the compressor power consumption, because it is offset by a higher isentropic specific work $\left(w_{c}\right)$, and both refrigerants generate a very similar $\mathrm{P}_{\mathrm{cH}}$ value.

The pressure ratio in HTC is practically equal for both refrigerants, so assuming the volumetric efficiency to be a function mainly of this parameter, R134a and R152a present the same value of $\eta_{v}$. In accordance with Equation 5, the compressor displacement should be higher ( $5 \%$ under the conditions simulated) if the plant works with R152a than if it works with R134a, since the reduction in mass flow rate is offset by the higher value in suction specific volume.

Finally, the slightly higher compressor power consumption for R134a than for R152a, and the equal $Q_{O L}$ value considered for both refrigerants results in a slightly higher COP value for R152a. 


\section{Experimental facility}

The experimental plant, which can be seen in Figure 2, corresponds to an R134a/R744 cascade refrigeration system designed to operate at the low evaporating temperature level of commercial refrigeration $\left(-40\right.$ to $\left.-30^{\circ} \mathrm{C}\right)$. The plant is driven by two single-stage reciprocating compressors: a $\mathrm{CO}_{2}$ variable speed semi-hermetic compressor for subcritical applications, with a displacement of $3.48 \mathrm{~m}^{3} / \mathrm{h}$ at $1450 \mathrm{rpm}$ and a nominal power of $1.5 \mathrm{~kW}$, which drives the LT cycle, and a variable speed semi-hermetic compressor, with a displacement of $32.66 \mathrm{~m}^{3} / \mathrm{h}$ at $1450 \mathrm{rpm}$ and nominal power of $3.7 \mathrm{~kW}$, dimensioned for R134a, which drives the single-stage HT cycle. The heat exchangers are of the brazed plate type with heat transfer surface areas of $2.39 \mathrm{~m}^{2}$ for the HT condenser, $2 \times 1.76 \mathrm{~m}^{2}$ for cascade condensers and $2.39 \mathrm{~m}^{2}$ for the LT evaporator. The facility incorporates electronic expansion valves. Figure 3 shows the schematic diagram of the plant, the position of the measurement devices and the designation. Next, we present the details of the plant, of the thermal support system and of the measurement instrumentation.

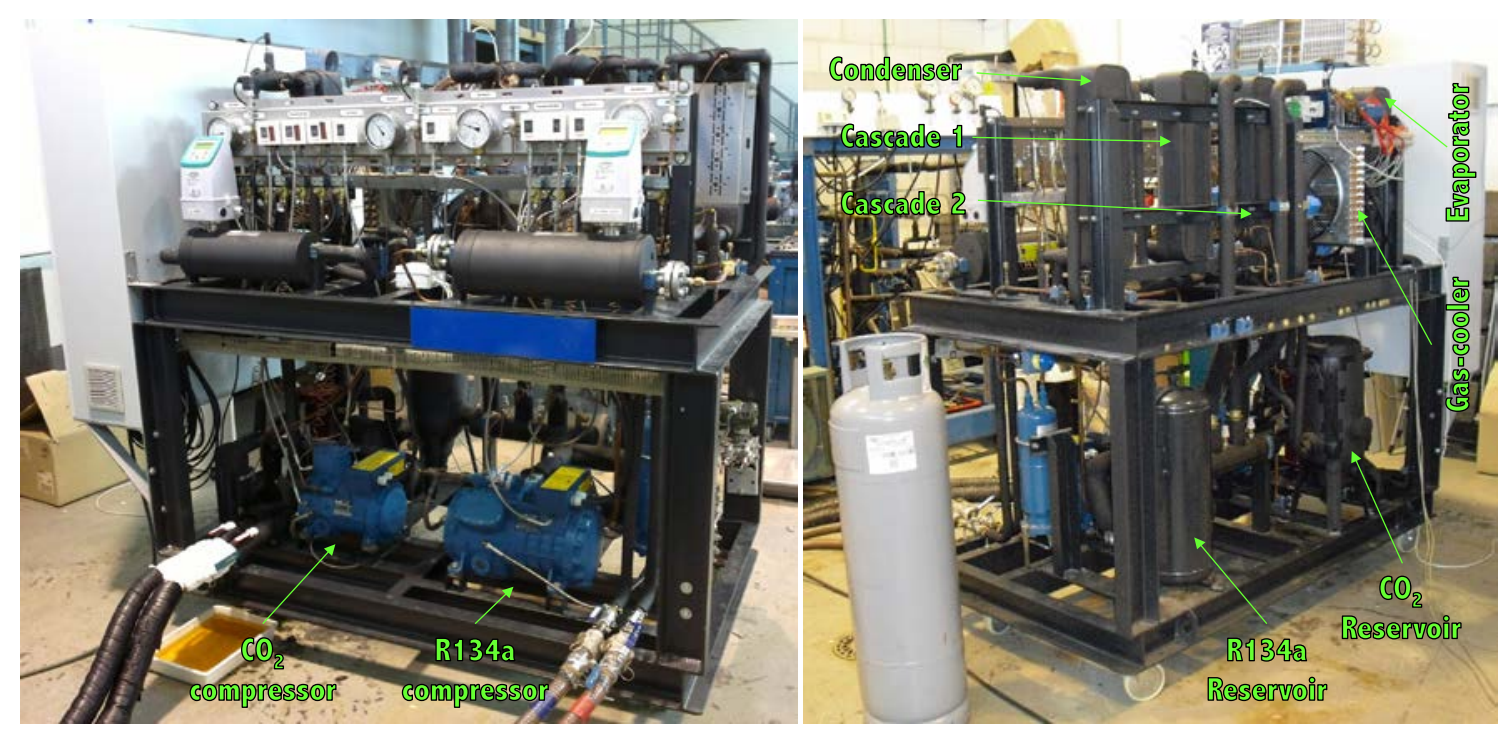

Figure 2. View of the cascade refrigeration plant. 


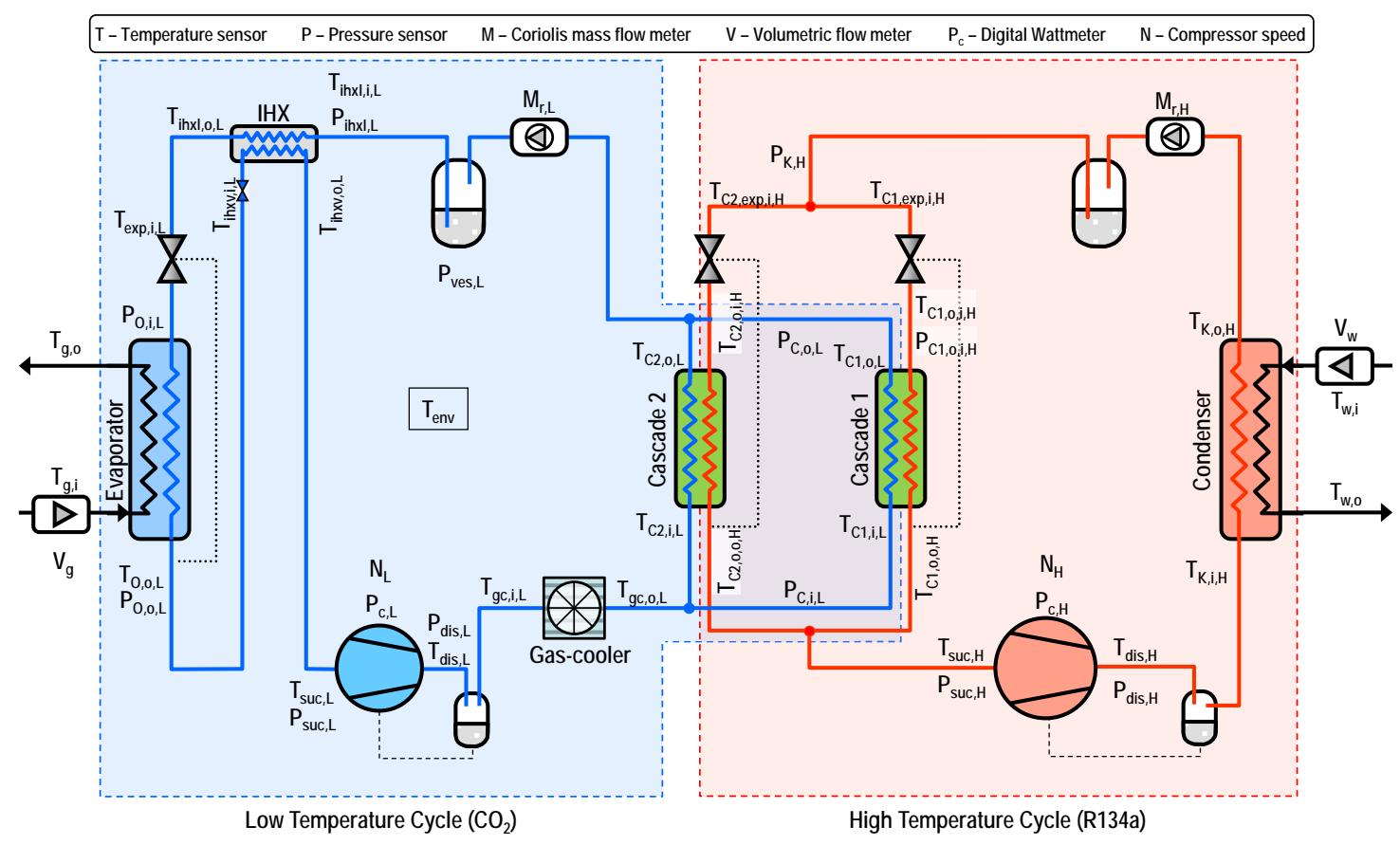

Figure 3. Schematic diagram of the experimental plant.

A more detailed description of the refrigeration facility, including the main characteristics of all the measurement instruments and their accuracies, can be obtained in C. Sanz-Kock et al. (2014), R. Llopis et al. (2015,b), and R. Llopis et al. (2016).

\section{Test campaign}

The R134a experimental results were extracted from the work published by Sanz-Kock et al. (2014). For comparison purposes, new tests were conducted with R152a in the same refrigeration facility, maintaining the same operating conditions.

The replacement of R134a with R152a was performed as a drop-in, and no changes were made in the facility or the lubricant. For a proper regulation of the electronic expansion valves, the R152a saturation curve was programmed in the expansion valve controller.

\subsection{Experimental procedure}

In order to conduct the tests, cascade refrigeration cycles present three degrees of freedom: HT condensing temperature $\left(T_{k, H}\right), L T$ evaporating temperature $\left(T_{0, L}\right)$, and temperature difference in the cascade condenser $\left(\Delta \mathrm{T}_{\text {casc }}\right)$.

For both refrigerants, the test campaign carried out to evaluate the performance of the cascade refrigeration system covered LT evaporating temperatures from -40 to $-30^{\circ} \mathrm{C}$ and $\mathrm{HT}$ condensing temperatures from 30 to $50^{\circ} \mathrm{C}$, these values being regulated and maintained by the secondary fluid loop 
systems. To perform $\Delta T_{\text {casc }}$ variations, for each combination of $T_{k H}$ and $T_{0 L}$ temperatures ( 9 tests), the operation of the cascade was registered regulating the HT compressor speed (five values). The LT compressor speed was maintained at its nominal value, because of its poor global efficiency, as explained in Sanz-Kock et al. (2014). Tests were carried out fixing $10^{\circ} \mathrm{C}$ of superheat in the expansion valves that feed the cascade condensers and the LT evaporator. Furthermore, the fan of the gas-cooler was always kept on, with a a constant consumption value of $75 \mathrm{~W}$.

Altogether, 45 steady-states of the plant were measured for each refrigerant, each lasting at least 20 minutes, with a sampling rate of 5 seconds and a maximum oscillation of the phase-change temperatures of $2 \%$, as detailed in Tables $5 a$ and $5 b$.

\begin{tabular}{|c|c|c|c|c|c|c|c|c|c|}
\hline$T_{0, L}$ & $T_{k, L}$ & $\Delta T_{S H, L}$ & $N_{L}$ & $T_{0, H}$ & $T_{k, H}$ & $\Delta T_{S H, H}$ & $\mathrm{~T}_{\text {env }}$ & $\mathrm{N}_{\mathrm{H}}$ & \\
\hline$\left({ }^{\circ} \mathrm{C}\right)$ & $\left({ }^{\circ} \mathrm{C}\right)$ & $\left({ }^{\circ} \mathrm{C}\right)$ & (rpm) & $\left({ }^{\circ} \mathrm{C}\right)$ & $\left({ }^{\circ} \mathrm{C}\right)$ & $\left({ }^{\circ} \mathrm{C}\right)$ & $\left({ }^{\circ} \mathrm{C}\right)$ & (rpm) & \\
\hline$-30 \pm 0,1$ & -6.6 to -0.6 & $9.3 \pm 0.2$ & 1450 & -10.9 to -4.4 & $30 \pm 0.1$ & $7.4 \pm 0.2$ & $27.5 \pm 1$ & 705 to 1108 & 5 \\
\hline$-35 \pm 0,1$ & -10.7 to -5.3 & $9.3 \pm 0.1$ & 1450 & -15.7 to -9.9 & $30 \pm 0.1$ & $7.7 \pm 0.3$ & $26.2 \pm 1.8$ & 806 to 1209 & 5 \\
\hline$-40 \pm 0,1$ & -13.2 to -7.9 & $9.3 \pm 0.1$ & 1450 & -19.3 to -13.6 & $30 \pm 0.1$ & $8.4 \pm 0.3$ & $27.1 \pm 1.5$ & 806 to 1209 & 5 \\
\hline$-30 \pm 0,1$ & -6.1 to -1.6 & $9.2 \pm 0.2$ & 1450 & -9.6 to -4.2 & $40 \pm 0.1$ & $7.4 \pm 0.5$ & $29.9 \pm 2$ & 806 to 1209 & 5 \\
\hline$-35 \pm 0,1$ & -9.2 to -3.8 & $9.2 \pm 0.1$ & 1450 & -13.4 to -7.7 & $40 \pm 0.1$ & $7.6 \pm 0.3$ & $30.0 \pm 1.3$ & 806 to 1209 & 5 \\
\hline$-40 \pm 0,1$ & -12.1 to -7.0 & $9.2 \pm 0.1$ & 1450 & -17.6 to -11.7 & $40 \pm 0.1$ & $7.8 \pm 0.3$ & $29.1 \pm 1.6$ & 806 to 1209 & 5 \\
\hline$-30 \pm 0,1$ & -4.6 to 0.9 & $9.1 \pm 0.1$ & 1450 & -7.8 to -2.0 & $50 \pm 0.1$ & $7.4 \pm 0.2$ & $28.0 \pm 1.2$ & 806 to 1209 & 5 \\
\hline$-35 \pm 0,1$ & -7.6 to -2.2 & $9.1 \pm 0.1$ & 1450 & -11.6 to -5.7 & $50 \pm 0.1$ & $7.6 \pm 0.2$ & $26.7 \pm 1.0$ & 806 to 1209 & 5 \\
\hline$-40 \pm 0,1$ & -11.4 to -7.6 & $9.1 \pm 0.1$ & 1450 & 16.8 to -12.4 & $50 \pm 0.1$ & $7.9 \pm 0.2$ & $27.9 \pm 1.2$ & 1007 to 1409 & 5 \\
\hline
\end{tabular}

Table 5a. Summary of the operating conditions maintained during tests performed with the cascade refrigeration plant using $\mathrm{R} 152 \mathrm{a} / \mathrm{CO}_{2}$.

\begin{tabular}{|c|c|c|c|c|c|c|c|c|c|}
\hline$T_{0, L}$ & $T_{k, L}$ & $\Delta \mathrm{T}_{\mathrm{SH}, \mathrm{L}}$ & $\mathrm{N}_{\mathrm{L}}$ & $T_{0, H}$ & $T_{k, H}$ & $\Delta \mathrm{T}_{\mathrm{SH}, \mathrm{H}}$ & $T_{\text {env }}$ & $\mathrm{N}_{\mathrm{H}}$ & eady- \\
\hline$\left({ }^{\circ} \mathrm{C}\right)$ & $\left({ }^{\circ} \mathrm{C}\right)$ & $\left({ }^{\circ} \mathrm{C}\right)$ & (rpm) & $\left({ }^{\circ} \mathrm{C}\right)$ & $\left({ }^{\circ} \mathrm{C}\right)$ & $\left({ }^{\circ} \mathrm{C}\right)$ & $\left({ }^{\circ} \mathrm{C}\right)$ & (rpm) & sta \\
\hline$-30 \pm 0,1$ & --4.9 to 0.2 & $9.0 \pm 0.2$ & 1450 & -9.17 to -3.43 & $30 \pm 0.1$ & $8.7 \pm 0.8$ & $27.5 \pm 1.6$ & 907 to 1310 & 5 \\
\hline$-35 \pm 0,1$ & -6.7 to -0.3 & $9.0 \pm 0.2$ & 1450 & -11.29 to -3.50 & $30 \pm 0.1$ & $10.0 \pm 0.5$ & $26.6 \pm 0.9$ & 705 to 1209 & 5 \\
\hline$-40 \pm 0,1$ & -11.5 to -4.8 & $9.0 \pm 0.2$ & 1450 & -17.10 to -9.52 & $30 \pm 0.1$ & $9.5 \pm 1.8$ & $24.3 \pm 1.3$ & 806 to 1409 & 5 \\
\hline$-30 \pm 0,1$ & -6.9 to -1.6 & $9.4 \pm 0.4$ & 1450 & -10.68 to -5.00 & $40 \pm 0.1$ & $9.5 \pm 0.6$ & $21.8 \pm 1.3$ & 806 to 1209 & 5 \\
\hline$-35 \pm 0,1$ & -11.0 to -6.3 & $9.3 \pm 0.3$ & 1450 & -15.29 to -10.28 & $40 \pm 0.1$ & $9.4 \pm 0.5$ & $21.4 \pm 1.4$ & 907 to 1310 & 5 \\
\hline$-40 \pm 0,1$ & -12.8 to -8.0 & $9.3 \pm 0.1$ & 1450 & -17.96 to -12.49 & $40 \pm 0.1$ & $9.6 \pm 0.4$ & $20.7 \pm 0.7$ & 806 to 1209 & 5 \\
\hline$-30 \pm 0,1$ & -9.2 to -3.8 & $9.3 \pm 1.1$ & 1450 & -12.71 to -7.25 & $50 \pm 0.1$ & $10.5 \pm 1.2$ & $22.7 \pm 0.7$ & 806 to 1209 & 5 \\
\hline$-35 \pm 0,1$ & -12.2 to -7.2 & $9.5 \pm 0.4$ & 1450 & -16.03 to -10.57 & $50 \pm 0.1$ & $9.7 \pm 1.1$ & $20.9 \pm 1.4$ & 806 to 1209 & 5 \\
\hline$-40 \pm 0,1$ & -15.4 to -10.3 & $9.4 \pm 0.1$ & 1450 & -20.15 to -14.43 & $50 \pm 0.1$ & $9.4 \pm 0.9$ & $20.0 \pm 1.1$ & 806 to 12097 & 5 \\
\hline
\end{tabular}

Table 5b. Summary of the operating conditions maintained during tests performed with the cascade refrigeration plant using $\mathrm{R} 134 \mathrm{a} / \mathrm{CO}_{2}$. 
Because a compressor dimensioned for R134a was mounted in the HT cycle and due to the greater specific volume of R152a with respect to R134a, the tests using R152a do not cover exactly the same compressor speed range, but there is sufficient overlap in both ranges to carry out the comparison.

\subsection{Data validation}

Data validation was carried out by comparing the heat transfer rates for the two fluid sides, in the main heat exchangers of the plant. The Equation 13 calculates the heat transfer rate dissipated from the refrigerant to the water at the HTC condenser, while the Equation 14 calculates the heat transfer rate absorbed by the water at the same heat exchanger.

$$
\begin{gathered}
\dot{Q}_{K, H}=\dot{m}_{r e f, H} \cdot\left(h_{k, i, H}-h_{k, o, H}\right) \\
\dot{Q}_{w}=\dot{V}_{w} \cdot \rho_{w} \cdot c_{p, w} \cdot\left(T_{w, o}-T_{w, i}\right)
\end{gathered}
$$

Equations 15 and 16 are used to calculate the heat transfer rate of rejection and absorption in the cascade heat exchanger, respectively. Due to the presence of two cascade condensers at the facility working in parallel (see figure 3), we have averaged the enthalpy difference of both cascade condensers.

$$
\begin{array}{cc}
\dot{Q}_{K, L}=\dot{m}_{r e f, L} \cdot 0,5 \cdot\left[\left(h_{C 1, k, i, L}-h_{C 1, k, o, L}\right)+\left(h_{C 2, k, i, L}-h_{C 2, k, o, L}\right)\right] & \text { Eq. } 15 \\
\dot{Q}_{O, H}=\dot{m}_{r e f, H} \cdot 0,5 \cdot\left[\left(h_{C 1, O, o, H}-h_{C 1, O, i, H}\right)+\left(h_{C 2, O, o, H}-h_{C 2, O, i, H}\right)\right] & \text { Eq. } 16
\end{array}
$$

With equations 17 and 18 is determined the cooling load provided by the secondary fluid and the heat transfer rate absorbed by the refrigerant at the evaporator

$$
\begin{array}{cc}
\dot{Q}_{s f}=\dot{V}_{s f} \cdot \rho_{s f} \cdot c_{p, s f} \cdot\left(T_{s f, i}-T_{s f, o}\right) & \text { Eq. } 17 \\
\dot{Q}_{O, L}=\dot{m}_{r e f, L} \cdot\left(h_{O, o, L}-h_{O, i, L}\right) & \text { Eq. } 18
\end{array}
$$

In Figures $6 \mathrm{a}$ and $6 \mathrm{~b}$ red dots are used to represent the heat transfer rate balance at the $\mathrm{HT}$ condenser using Equations 13 and 14, green diamonds represent the heat transfer rate balance at the cascade condenser using Equations 15 and 16, and blue squares represent the heat transfer rate balance at the LT evaporator using Equations 17 and 18.

Regarding the heat balance at the $\mathrm{HT}$ condenser, $99.6 \%$ of the values present a deviation below $\pm 10 \%$, at the cascade heat exchanger $97.0 \%$ of data are within $\pm 10 \%$, and $92.4 \%$ of the data in the LT evaporator deviate less than $\pm 10 \%$. 


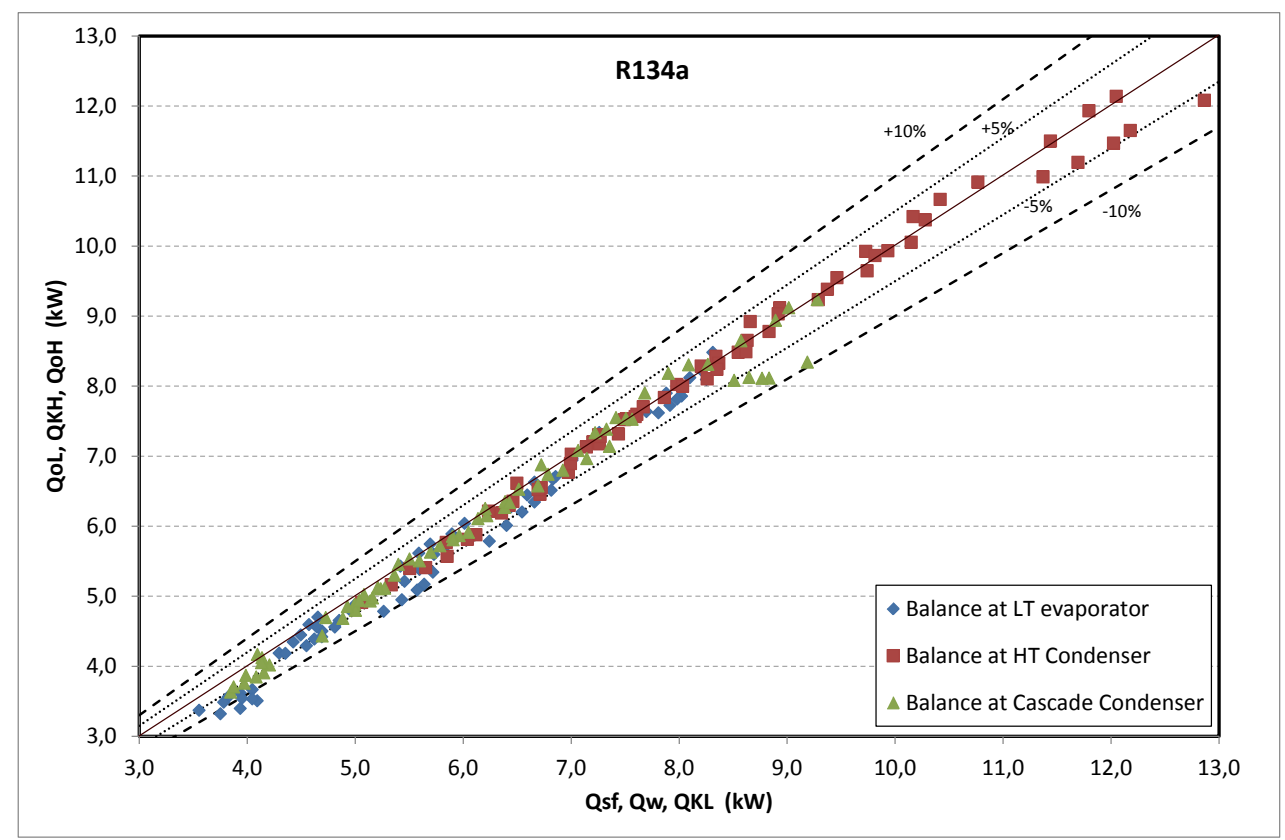

Figure 4a. Validation of heat transfer rates in the cascade plant using R134a/R744.

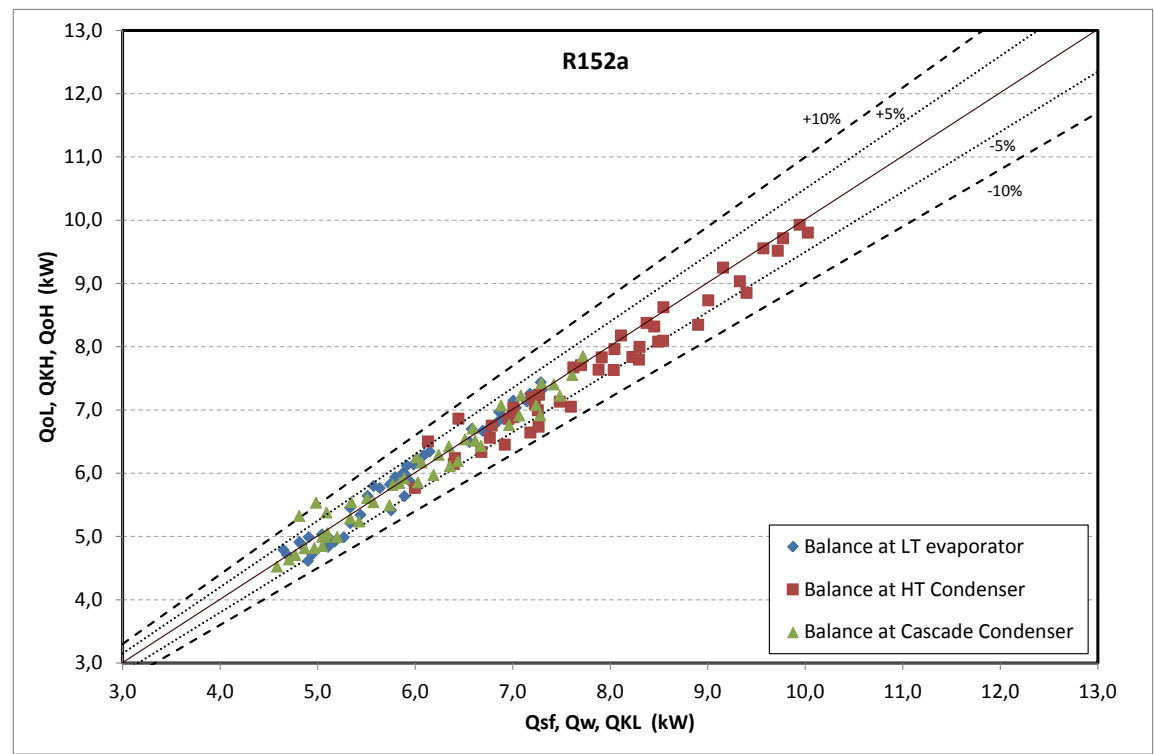

Figure 4b. Validation of heat transfer rates in the cascade plant using R152a/R744.

The heat transfer rate balances show good concordance in both fluids for each heat exchanger, which confirms the accuracy of the measurements.

\section{Results and discussion}

In order to obtain greater clarity, the analysis is performed showing the results for the two extreme operating conditions, which are when the temperature difference between the heat sink and the cold source are maximum $\left(T_{k H}=50^{\circ} \mathrm{C}\right.$ and $\left.T_{o L}=-40^{\circ} \mathrm{C}\right)$ and minimum $\left(T_{k H}=30^{\circ} \mathrm{C}\right.$ and $\left.T_{o L}=-30^{\circ} \mathrm{C}\right)$. 
When the operating conditions are the same, we have measured that the $\mathrm{CO}_{2}$ mass flow rate is practically the same, regardless of the refrigerant charged in the HT cycle. Nevertheless, due to the difference in specific volume, for the same compressor displacement and the same operating conditions, the R134a mass flow rate is nearly twice that of R152a. This difference is practically constant for all the operating conditions tested.

Regarding the $\Delta T_{\text {casc., }}$ in Figures $5 \mathrm{a}, 5 \mathrm{~b}$ and $5 \mathrm{c}$ we represent its values for three operating conditions. As could be expected, for both refrigerants it can be observed that $\Delta T_{\text {casc. }}$ decreases when the mass flow rate is reduced, that is, when the compressor rotation speed is lower, and when the difference between the heat sink and the cold source increases.

In terms of comparing R134a and R152a, the cascade condenser presents a lower $\Delta T_{\text {casc. }}$ value when the plant is working with R134a. But, as the temperature difference between the heat sink and the cold source

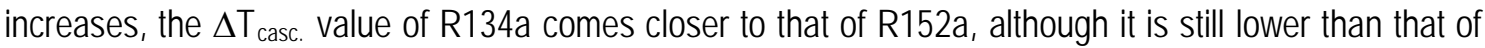
R152a for the maximum temperature difference.
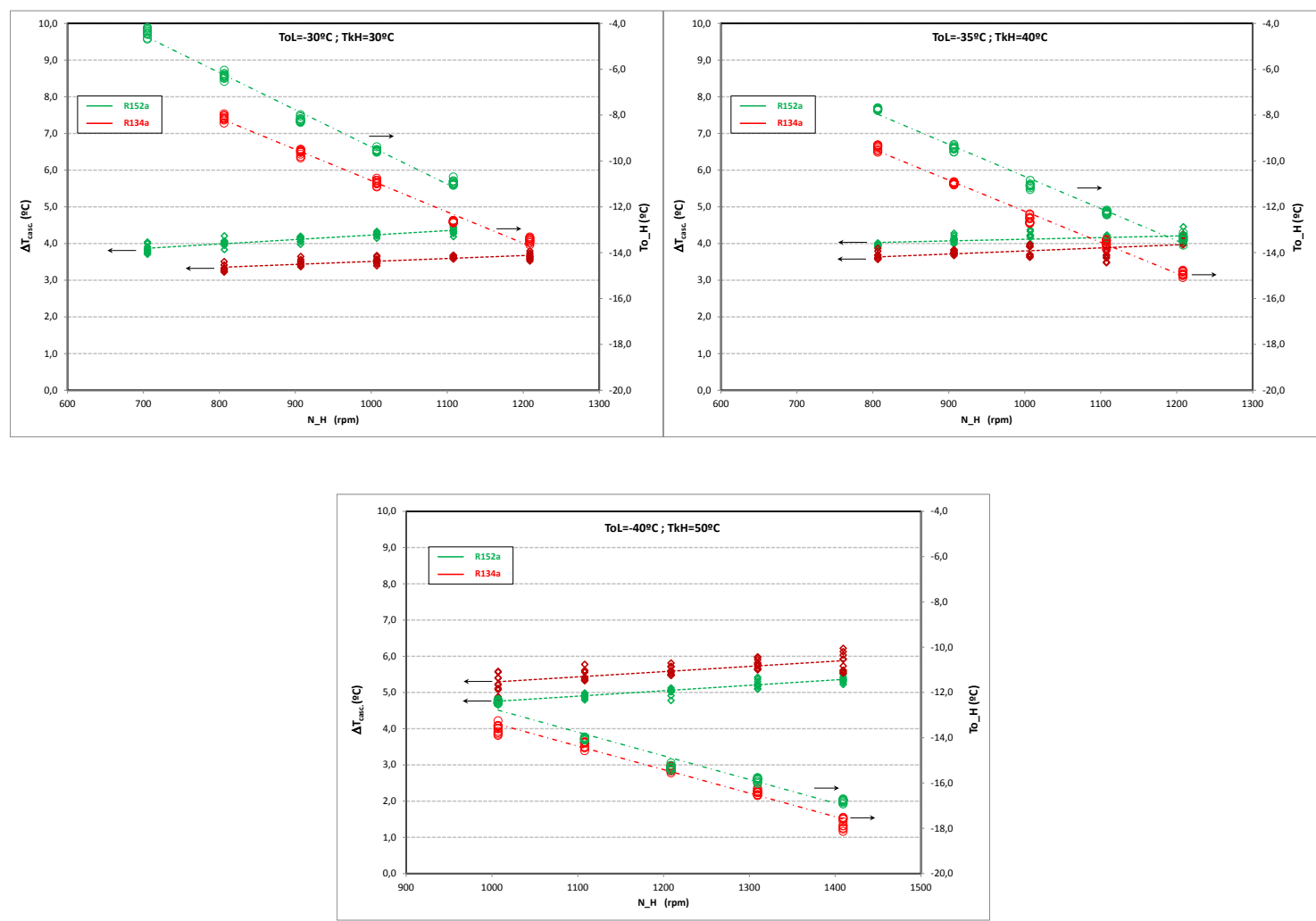

Figures $5 \mathrm{a}, 5 \mathrm{~b}$ and $5 \mathrm{c}$. Evolution of $\Delta \mathrm{T}_{\text {casc. and }} \mathrm{T}_{\mathrm{OH}}$ with $\mathrm{T}_{\mathrm{kH}}, \mathrm{T}_{\mathrm{oL}}$ and $\mathrm{N}_{\mathrm{H}}$ evolution for different operating conditions.

The difference in $\Delta T_{\text {casc. }}$ when the plant is working with R134a or with R152a, together with the modifications in the compressor speed, are the main variables not considered in the theoretical analysis. 
Another parameter represented in Figures $5 a, 5 b$ and $5 c$ is the $H T$ evaporating temperature $\left(T_{0, H}\right)$. For the whole range of $T_{k, H}$ and $T_{0, L}$ tested, the R152a evaporating temperature is between $1{ }^{\circ} \mathrm{C}$ and $2^{\circ} \mathrm{C}$ higher with respect to that of R134a. This fact means that, as the saturation pressures are equal for both refrigerants in the range of evaporating temperatures tested, the HT compressor works with a lower pressure ratio if the facility is charged with R152a than if it is charged with R134a. The variation in HT pressure ratio does not affect that of $L T$, because the higher $T_{0, H}$ value with R152a is offset by the higher $\Delta T_{\text {casc., }}$ resulting in a very similar $L T$ pressure ratio (see Figures $6 a$ and $6 \mathrm{~b}$ ).

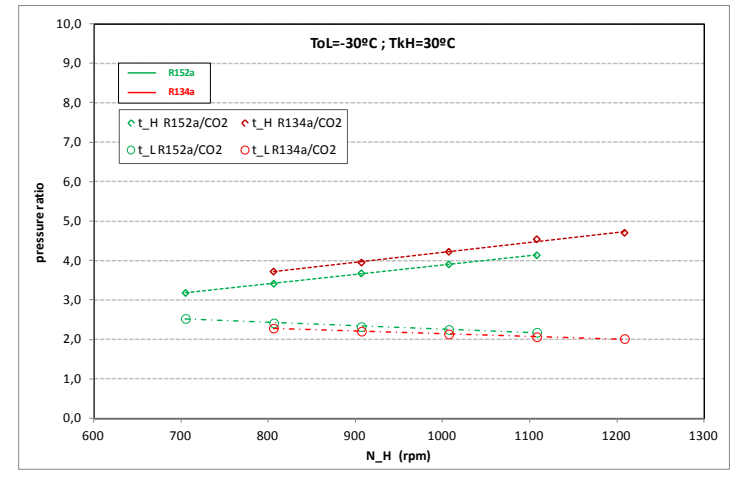

Figure 6a. Pressure ratio in High and Low temperature cycles, working at $\mathrm{T}_{\mathrm{oL}}=-30^{\circ} \mathrm{C}$ and $\mathrm{T}_{\mathrm{kH}}=30^{\circ} \mathrm{C}$.

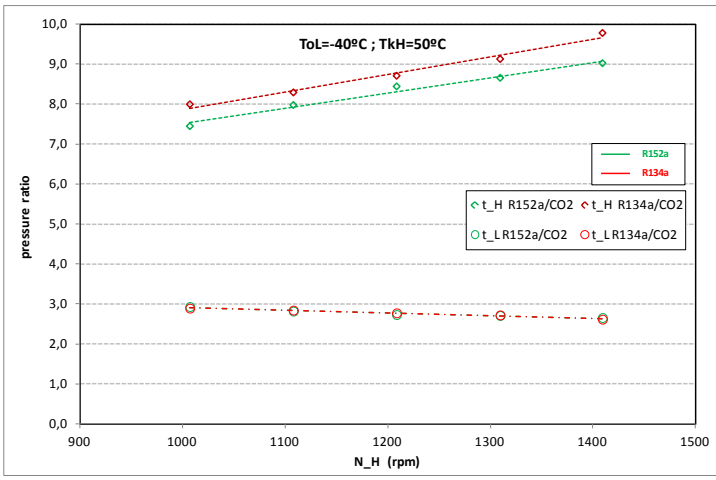

Figure 6b. Pressure ratio in High and Low temperature cycles, working at $\mathrm{T}_{\mathrm{oL}}=-40^{\circ} \mathrm{C}$ and $\mathrm{T}_{\mathrm{kH}}=50^{\circ} \mathrm{C}$.

In Figures $7 \mathrm{a}$ and $7 \mathrm{~b}$, the main heat transfer rates obtained at the LT evaporator $\left(Q_{o, L}\right)$, HT condenser $\left(\dot{Q}_{k, H}\right)$, and Cascade condenser $\left(\dot{Q}_{k, L}\right)$ are depicted for the two extreme operating conditions tested.

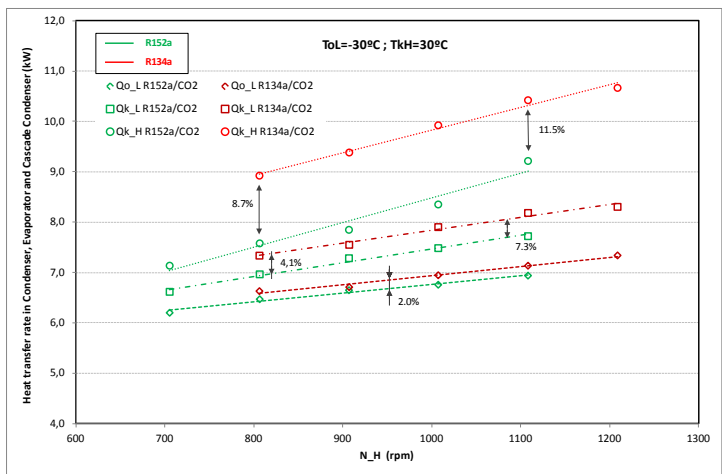

Figure 7a. Main Heat transfer rates in the cascade refrigeration facility at $\mathrm{ToL}=-30^{\circ} \mathrm{C}$ and $\mathrm{TkH}=30^{\circ} \mathrm{C}$.

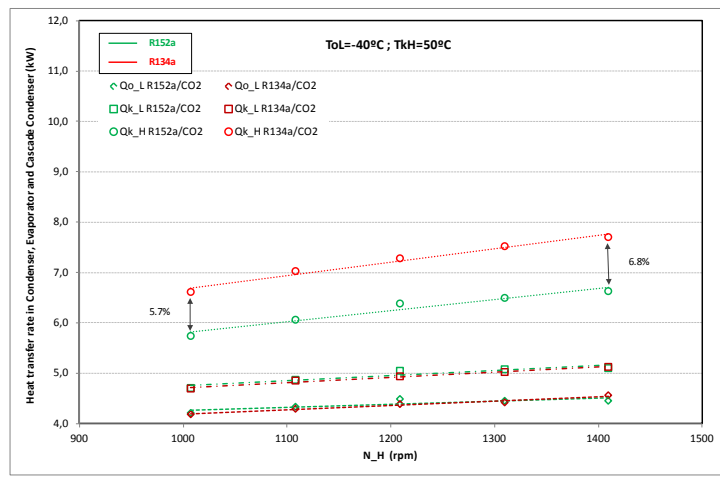

Figure $7 \mathrm{~b}$. Main Heat transfer rates in the cascade refrigeration facility at $\mathrm{ToL}=-40^{\circ} \mathrm{C}$ and $\mathrm{TkH}=50^{\circ} \mathrm{C}$.

From the depicted data we can conclude that the utilization of R152a as the working fluid instead of R134a results in lower heat transfer rates. The cooling capacity at the LT evaporator presents the lowest difference, being below $2 \%$ over the whole range of operating conditions tested. In contrast, the heat rejected at the HT condenser presents the greatest differences between refrigerants, owing to the cumulative effect of the power consumption differences at the compressors and the heat absorbed at the evaporator and the cascade condenser. 
Taking into account the differences in refrigerant mass flow rates in the HT cycle and those in the heat transfer rates, the greater latent heat of evaporation and condensation of R152a with respect to that of R134a plays an important role in equalizing the energy behavior of the cascade plant when R134a is replaced with $\mathrm{R} 152 \mathrm{a}$.

The gas-cooler placed following the compressor discharge in the LT cycle (see Figure 3) rejects a considerable amount of heat to the environment (around 1kW, depending on the environmental temperature). This is why the difference between heat transfer rates at evaporation and condensation levels in the LT cycle is much lower than in the HT cycle, for both refrigerants R134a and R152a.

The power consumption of the two compressors and their corresponding global efficiency, calculated according to Equation 19, are shown in Figures $8 \mathrm{a}$ and $8 \mathrm{~b}$ for the minimum and maximum temperature difference of the heat sink and the cold source.

$$
\eta_{G}=\frac{\dot{m}_{r e f .} \cdot w_{c S}}{P_{c}}
$$

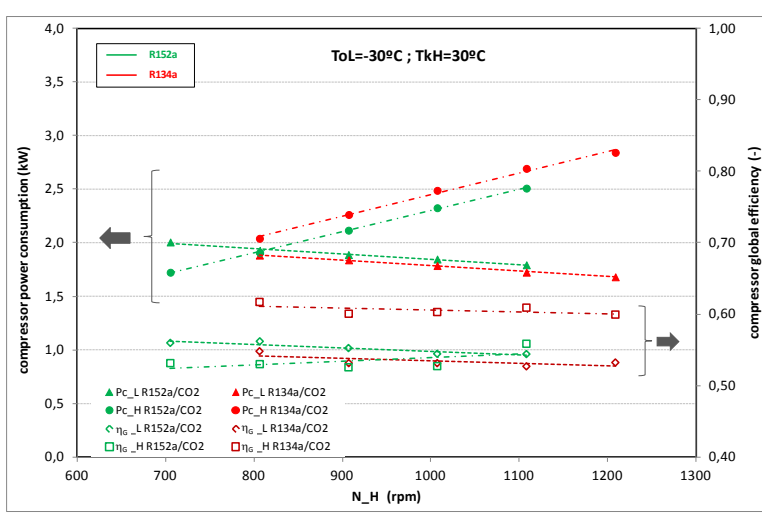

Figure 8a. Power consumption and global efficiency of compressors at $\mathrm{ToL}=-30^{\circ} \mathrm{C}$ and $\mathrm{TkH}=30^{\circ} \mathrm{C}$.

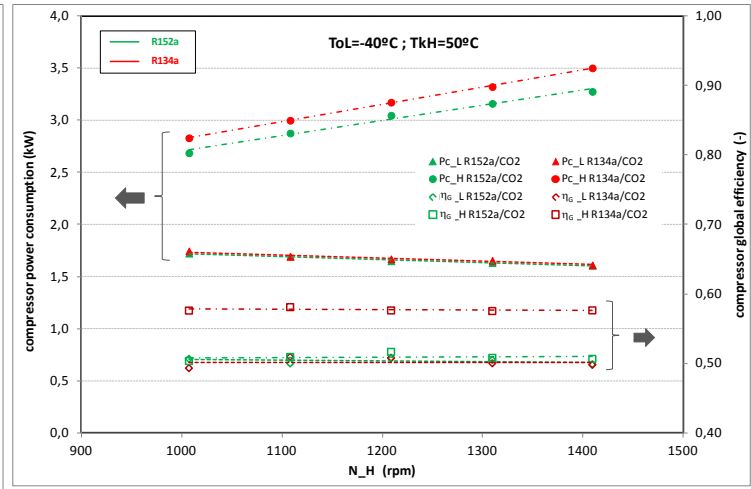

Figure $8 \mathrm{~b}$. Power consumption and global efficiency of compressors at $\mathrm{ToL}=-40^{\circ} \mathrm{C}$ and $\mathrm{TkH}=50^{\circ} \mathrm{C}$.

The power consumption measured in the $\mathrm{CO} 2$ compressor is practically the same regardless of whether R134a or R152a is used in the HT cycle, while the HT cycle compressor consumes less power when the refrigeration plant uses R152a as the working fluid than if it uses R134a.

Notwithstanding, a poorer global efficiency (between $5 \%$ and $8 \%$ ) is revealed when the compressor mounted in the HT cycle works with R152a in comparison to that obtained when it works with R134a. Regarding Equation 19, this reduction in efficiency occurs despite the reduction in compressor power consumption and the increase in the isentropic specific compression work. Therefore, we can conclude that the refrigerant mass flow rate is the leading factor that determines the global efficiency.

All the issues commented in this section are summarized in Figure 9, where a Sankey diagram is presented for the cascade refrigeration plant working under fixed conditions. This figure shows the 
reduction in heat transfer rates and in compressor power consumption when R152a is the working fluid used in the HT cycle, instead of R134a. Nevertheless the differences are not significant.
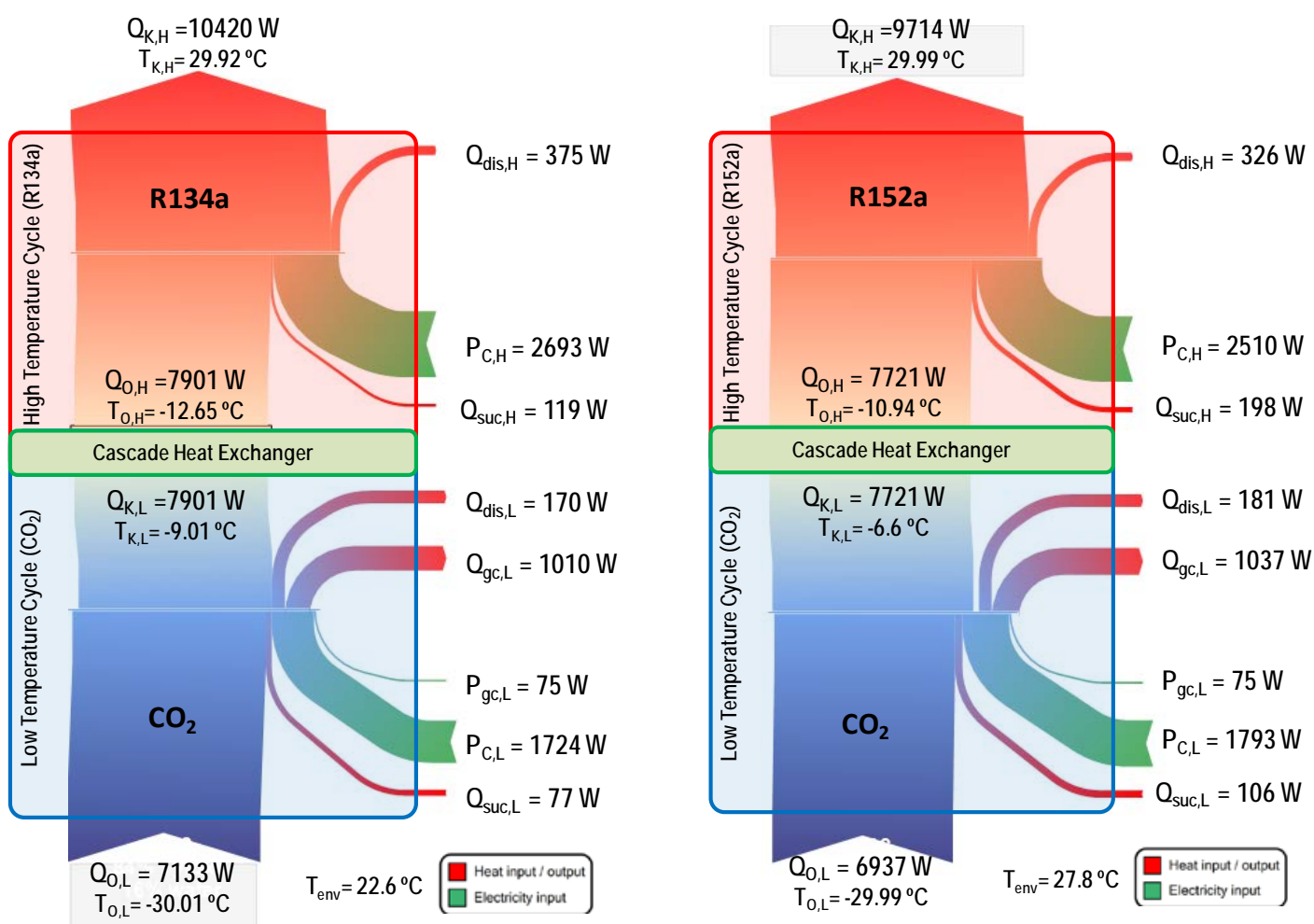

Figure 9. Energy flow through the cascade plant at $T_{0, L}=-30.0^{\circ} \mathrm{C}, T_{k, H}=30.0^{\circ} \mathrm{C}, N_{L}=1450 \mathrm{rpm}, N_{H}=1108 \mathrm{rpm}$.

The COP of the high and low temperature cycles, $\mathrm{COP}_{\mathrm{LT}}$ and $\mathrm{COP}_{H \mathrm{HT}}$ respectively, together with the COP of the whole cascade refrigeration facility $\left(\mathrm{COP}_{\mathrm{T}}\right.$ ) have been calculated using Equations 20,21 and 22 respectively, for the minimum and maximum difference in hot and cold temperature sources, in the same way as was already carried out with the other parameters discussed above.

$$
\begin{gathered}
C O P_{L}=\frac{\dot{Q}_{0 L}}{P_{c L}+P_{g c}} \\
C O P_{H}=\frac{\dot{Q}_{0 H}}{P_{c H}} \\
\operatorname{COP}_{T}=\frac{\dot{Q}_{0 L}}{P_{c L}+P_{g c}+P_{c H}}
\end{gathered}
$$

The results obtained are depicted in Figures 10a and 10b. In these figures we can observe that there is no substantial difference between the energy efficiency of the refrigeration facility $\left(\mathrm{COP}_{\mathrm{T}}\right)$ when working with either of the two refrigerants in the high temperature cycle (R134a or R152a). 
Another issue that is observed in Figures $10 \mathrm{a}$ and $10 \mathrm{~b}$ is the independence of $\mathrm{COP}_{\mathrm{T}}$ with the compressor speed under both operating conditions and with both refrigerants. This means that regulation using an inverter does not affect the energy performance of the cascade refrigeration plant.

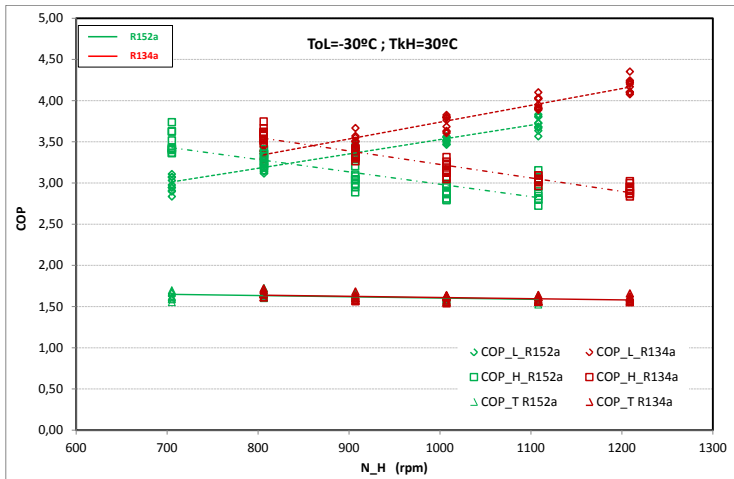

Figure 10a. Energy Efficiency of the HT and LT cycles calculated separately ( $\mathrm{COP}$ and $\left.\mathrm{COP}_{\mathrm{H}}\right)$ and connected in cascade $\left(\mathrm{COP}_{\mathrm{T}}\right)$ at $\mathrm{T}_{\mathrm{oL}}=-30^{\circ} \mathrm{C}$ and $\mathrm{T}_{\mathrm{kH}}=30^{\circ} \mathrm{C}$.

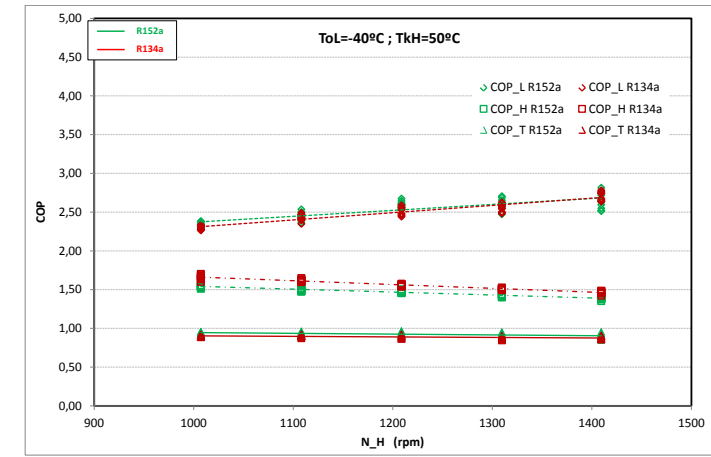

Figure 10b. Energy Efficiency of the HT and LT cycles calculated separately (COPL and $\left.\mathrm{COP}_{\mathrm{H}}\right)$ and connected in cascade $(\mathrm{COP} T) \mathrm{T}_{\mathrm{OL}}=-40^{\circ} \mathrm{C}$ and $\mathrm{T}_{\mathrm{kH}}=50^{\circ} \mathrm{C}$.

In general, these results obtained for $\mathrm{COP}_{\mathrm{H}}$ agree with those published by R. Cabello et al. (2015) for a single stage vapor compression plant. In that publication, R134a shows better energy performance than R152a for high evaporating temperatures, this difference tending to be reduced until it practically disappears as the evaporating temperature is lowered, which means $T_{0}=-10^{\circ} \mathrm{C}$.

This section finishes with Tables $6 a$ and $6 \mathrm{~b}$, which show a summary of the data collected and the main energy parameters when the refrigeration plant is working at compressor speeds of $1108 \mathrm{rpm}$ and 1007 rpm for the HT cycle compressor, and 1450 rpm for the LT cycle compressor.

One of the parameters shown in these tables is the discharge temperature, which has not been considered so far. From the measured data, an increase in this parameter, ranging from $9{ }^{\circ} \mathrm{C}$ to $15^{\circ} \mathrm{C}$, can be observed when the HT compressor is working with R152a instead of R134a, this increase. This fact is in agreement with the mass flow rate, because the lower the mass flow rate, the higher the compressor discharge temperature is, as depicted in Figure 11. In the LT cycle there is also an increase in the discharge temperature, due to the lower $\mathrm{CO}_{2}$ mass flow rate moved by the LT compressor when R152a is working in the HT cycle. 


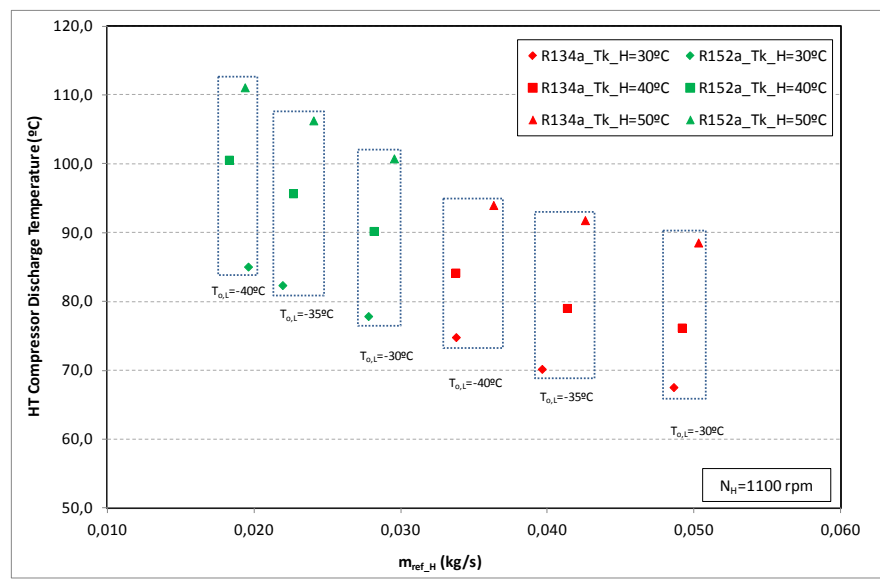

Figure 11. Compressor discharge temperatures versus refrigerant mass flow rate, both in the HT cycle, when the compressor is running at $1100 \mathrm{rpm}$ under different operating conditions.

In general, we can conclude that the results obtained from the experimental data are in accordance with those obtained in the theoretical analysis. The discrepancies lie in the assumptions made in the theoretical study concerning the same $\Delta \mathrm{T}_{\text {casc }}$, and in considering a different $\mathrm{HT}$ compressor displacement for each refrigerant.

\section{Conclusions}

Using the same cascade refrigeration facility, a full test campaign was carried out covering a wide range of operating conditions: $T_{0}$ L was varied from $-30^{\circ} \mathrm{C}$ to $-40^{\circ} \mathrm{C}, T_{\mathrm{kH}}$ was varied from from $30^{\circ} \mathrm{C}$ to $50^{\circ} \mathrm{C}$, and the HT cycle compressor speed was varied from $800 \mathrm{rpm}$ to $1400 \mathrm{rpm}$. These operating conditions were tested using R134a and R152a as the working fluids in the HT cycle, and $\mathrm{CO} 2$ as the refrigerant pair for both cases in the LT cycle.

The refrigeration plant is designed for the refrigerant pair $\mathrm{R} 134 \mathrm{a} / \mathrm{CO} 2$, and a drop-in replacement of R134a with R152a was performed, which involves no changes or substitution of equipment or lubricant, only the adjustment of internal parameters in the electronic expansion valve for a proper regulation.

The refrigeration plant worked correctly for two months using R152a as the refrigerant in the high temperature cycle. This fact confirms the feasibility of using this working fluid in the HT cycle of cascades.

In general, for the same operating conditions, the energy behaviour of the plant does not show great differences when it is working with any of the two refrigerants. It could be highlighted that the results are slightly better for R134a, when the temperature difference between hot and cold source are lower, but as this difference becomes greater, the cascade refrigeration plant, presents better energy results when works with R152a. The discharge temperatures measured at the $\mathrm{HT}$ cycle compressor are between $10^{\circ} \mathrm{C}$ 
and $15^{\circ} \mathrm{C}$ higher when the working fluid is R152a. This rise supposes that discharge temperature reach in some tests $120^{\circ} \mathrm{C}$, what implies the need of a lubricant of higher quality.

This work presents a comparative analysis from an energy and technical point of view, leaving aside security and cost issues regarding the flammability of R152a, the refrigerant charge needed, and the market price of both refrigerants.

\section{Acknowledgments}

The authors gratefully acknowledge the financial support for the present work provided by the Spanish Ministry of Economy and Competitiveness (research project ENE2014-53760-R)

\section{References}

AREA, 2011. Low GWP Refrigerants Guidance on use and basic competence requirements for contractors June 2011

http://www.area-eur.be/_Rainbow/Documents/AREA+-+PP+Low+GWP+refrigerants+(110629).pdf

Arora, S.C. Kaushik Theoretical analysis of a vapour compression refrigeration system with R502, R404A and R507A Int. J. Refrigeration, 31 (2008), pp. 998-1005

ASHRAE Handbook CD, 2001 Edition, American Society of Heating, Refrigerating and Air Conditioning Engineers, Englewood, Colorado (USA), 2001.

ASHRAE, 2013. Designation and Safety Classification of Refrigerants, Standard 34-2013. ISSN:10412336. 2013

C. Sanz-Kock, R. Llopis, D. Sánchez, R. Cabello, E. Torrella, 2014. Experimental evaluation of a R134a/CO2 cascade refrigeration plant, Applied Thermal Engineering, Volume 73, Issue 1, 5 December 2014, Pages 41-50, ISSN 1359-4311

Calm J. M., 2012. Refrigerant transitions... again. Moving towards sustainability. In: ASHRAE/NIST Conference, $29 \quad-\quad 30$ October, Gaithersburg, MD, USA, (http://nccashrae.org/images/meeting/031214/calm im 2012. refrigerant transitions ... again. ashrae $\underline{\text { nist refrigerants conference.pdf) }}$

E. Granryd, I. Ekroth, P. Lundqvist, A. Melinder, B. Palm, P. Rohlin, 2009 Refrigerating Engineering KTH, Department of Energy Technology. ISBN: 978-91-7415-415-3

European Commission, 2005. Council of the European Union. Presidency Conclusions - Brussels, 22/23 March 2005. 
European Commission, 2014. Regulation (EU) No 517/2014 of the European Parliament and of the Council of 16 April 2014 on fluorinated greenhouse gases and repealing Regulation (EC) No 842/2006.

IPCC, 2013: Climate Change 2013: The Physical Science Basis. Contribution of Working Group I to the Fifth Assessment Report of the Intergovernmental Panel on Climate Change [Stocker, T.F., D. Qin, G.-K. Plattner, M. Tignor, S.K. Allen, J. Boschung, A. Nauels, Y. Xia, V. Bex and P.M. Midgley (eds.)]. Cambridge University Press, Cambridge, United Kingdom and New York, NY, USA, 1535 pp

IPCC, 2014: Climate Change 2014: Synthesis Report. Contribution of Working Groups I, II and III to the Fifth Assessment Report of the Intergovernmental Panel on Climate Change [Core Writing Team, R.K. Pachauri and L.A. Meyer (eds.)]. IPCC, Geneva,Switzerland, 151 pp.

J.M. Calm, 2008. The next generation of refrigerants - historical review, considerations, and outlook International Journal of Refrigeration, 31 (2008), pp. 1123-1133

Kauffeld, Michael. 2008. "Trends and Perspectives in Supermarket Refrigeration." International Technical Meeting on HCFC phase-out 05/04/2008. . The Directorate-General for Climate Action. Available online at: http://ec.europa.eu/clima/events/articles/0007_en.htm Accessed October 30, 2015.

Lemmon E. W., Huber M. L., McLinden M. O., 2013. Reference fluid thermodynamic and transport properties (REFPROP), NIST Standard Reference Database 23, v.9.1. National Institute of Standards 2013. Gaithersburg MD, USA.

Law, 2013. Ley 16, 2013, de 29 de octubre, por la que se establecen determinadas medidas en materia de fiscalidad medioambiental $y$ se adoptan otras medidas tributarias $y$ financieras. https://www.boe.es/buscar/act.php?id=BOE-A-2013-11331.

M. Beshr, V. Aute, V. Sharma, O. Abdelaziz, B. Fricke, R. Radermacher, 2015. A comparative study on the environmental impact of supermarket refrigeration systems using low GWP refrigerants. International Journal of Refrigeration, Volume 56, August 2015,Pages 154-164

M. Meinshausen, N. Meinshausen, W. Hare, S. C. B. Raper, K. Frieler, R. Knutti, D. J. Frame and M. R. Allen, 2009. "Greenhouse-gas emission targets for limiting global warming to $2^{\circ} \mathrm{C}$." Nature $458(7242)$ : 1158

M. Mohanraj, S. Jayaraj, C. Muraleedharan, 2009. Environment friendly alternatives to halogenated refrigerants-a review Int. J. Greenh. Gas Control, Volume 3, pp. 108-119 
O. Abdelaziz, B. Fricke, E. Vineyard, 2012. Development of low global warming potential refrigerant solutions for commercial refrigeration systems using a life cycle climate performance design tool. In: 14th International Refrigeration and Air Conditioning Conference. Purdue University, West Lafayette, Indiana.

R. Cabello, D. Sánchez, R. Llopis, I. Arauzo, E. Torrella. 2015. Experimental comparison between R152a and R134a working in a refrigeration facility equipped with a hermetic compressor, International Journal of Refrigeration, Volume 60, Pages 92-105

R. Llopis, D. Sánchez, C. Sanz-Kock, R. Cabello, E. Torrella. 2015,a. Energy and environmental comparison of two-stage solutions for commercial refrigeration at low temperature: Fluids and systems, Applied Energy, Volume 138, Pages 133-142

R. Llopis, C. Sanz-Kock, R. Cabello, D. Sánchez, E. Torrella. 2015,b. Experimental evaluation of an internal heat exchanger in a $\mathrm{CO} 2$ subcritical refrigeration cycle with gas-cooler, Applied Thermal Engineering, Volume 80, Pages 31-41

R. Llopis, C. Sanz-Kock, R. Cabello, D. Sánchez, L. Nebot-Andrés, J. Catalán-Gil. 2016. Effects caused by the internal heat exchanger at the low temperature cycle in a cascade refrigeration plant, Applied Thermal Engineering, Available online 19 April 2016

RD, 2013. Royal Decree 1042/2013, dated 27 December, which passes the Fluorinated Greenhouse Gases Tax Regulation, and which modifies the Regulation of the Procedure for the exercise of disciplinary power, approved by Royal Decree 1398/1993, dated 4 August, the Corporation Tax Regulation, passed by Royal Decree 1777/2004, dated 30 July, the Income Tax Regulation, approved by Royal Decree 439/2007, dated 30 March, and the Value Added Tax Regulation, approved by Royal Decree 1624/1992, dated 29 December. (Official State Gazette, 30-December-2013

Vishaldeep Sharma, Brian Fricke, Pradeep Bansal, 2014. Comparative analysis of various CO2 configurations in supermarket refrigeration systems, International Journal of Refrigeration, Volume 46, October 2014, Pages 86-99,

W.B. Gosney, 1982. Principle of refrigeration. Cambridge University Press. ISBN: 0521236711

W. Goetzler, T. Sutherland, M. Rassi, J. Burgos, 2014. Research \& Development Roadmap for NextGeneration Low Global Warming Potential Refrigerants, November 2014, Prepared by Navigant Consulting, Inc for U.S. Department of Energy Office of Energy Efficiency and Renewable Energy Building Technologies Office http://www.energy.gov/eere/buildings/downloads/research-development-roadmap$\underline{\text { next-generation-low-global-warming-potential }}$ 


\section{Figures}

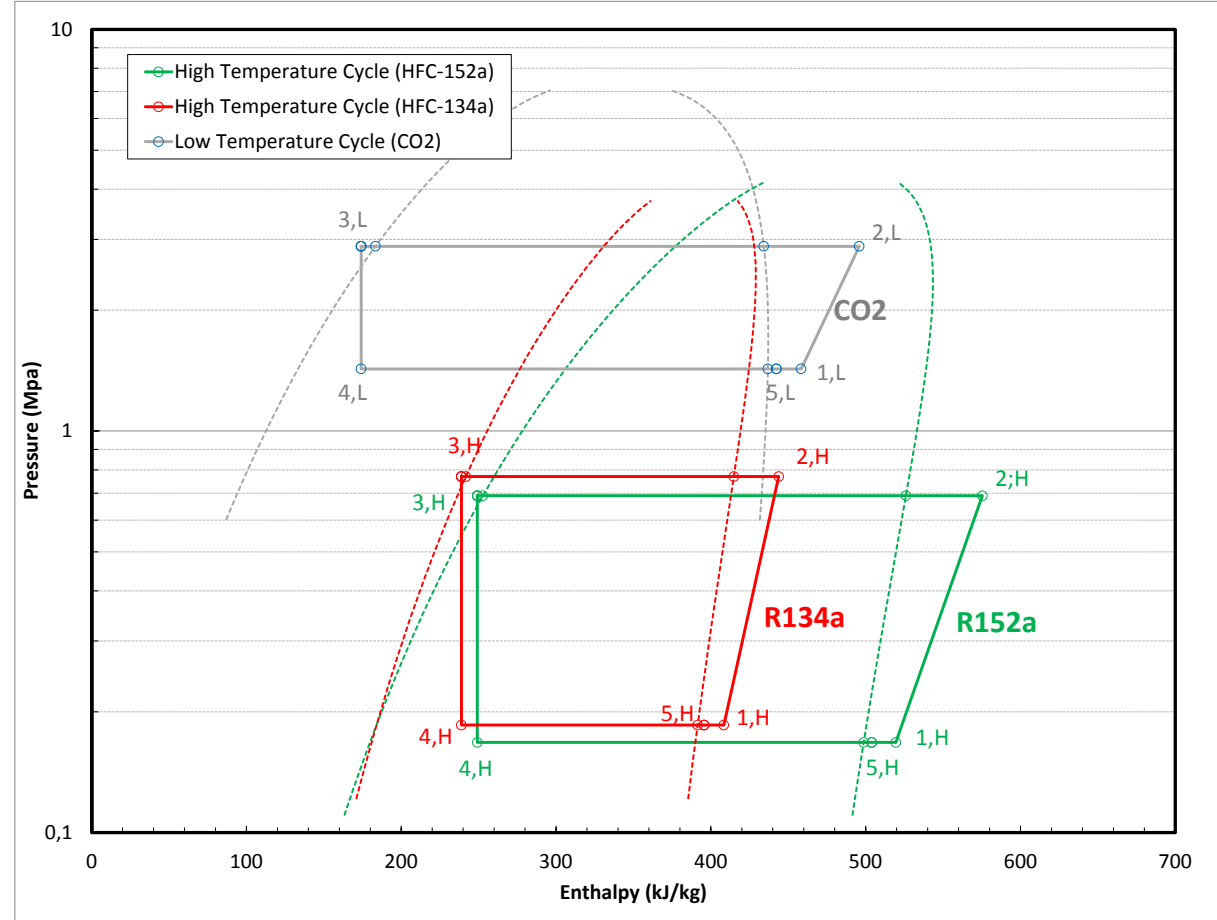

Figure 1. Comparison of the theoretical cascade cycles for R134a/R744 and R152a/R744 


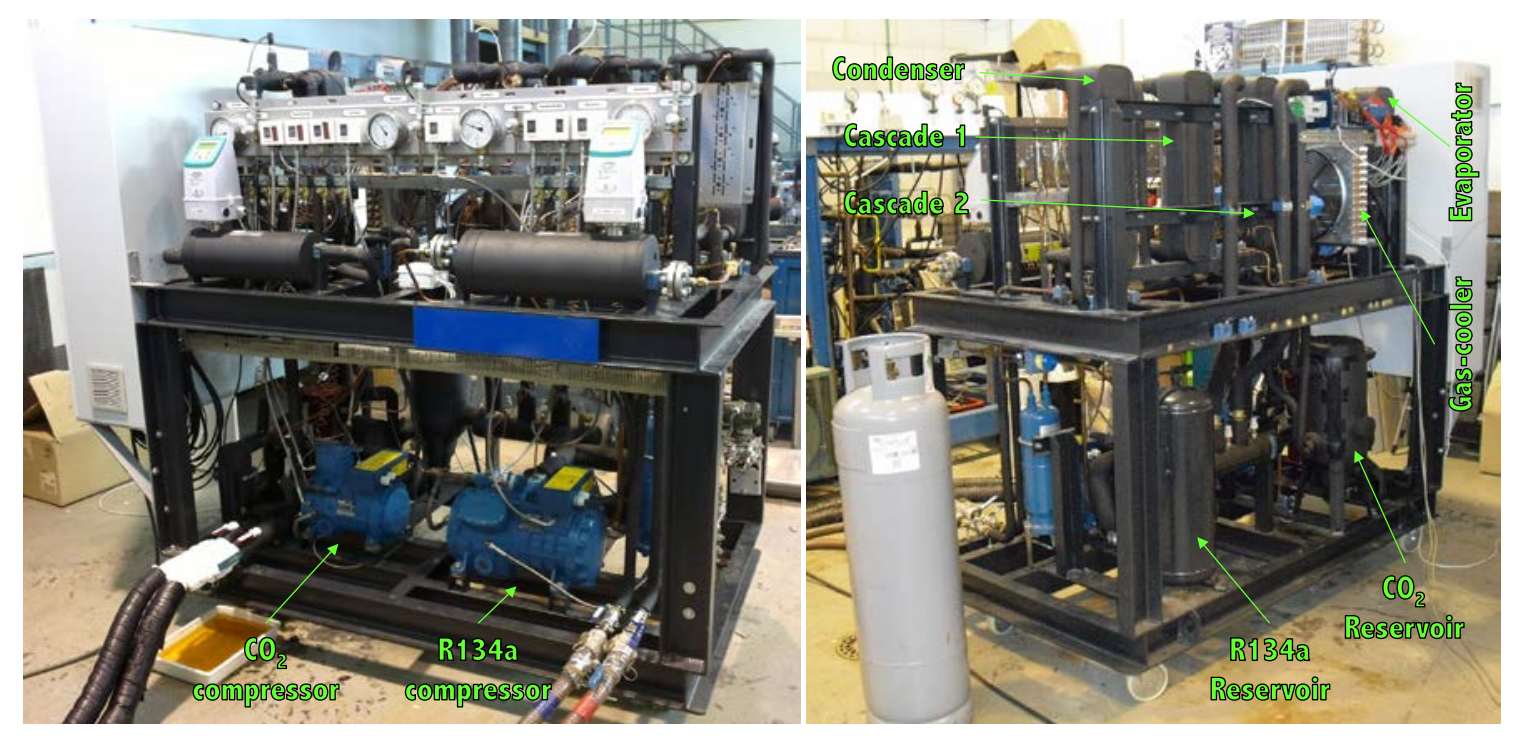

Figure 2. View of the cascade refrigeration plant 


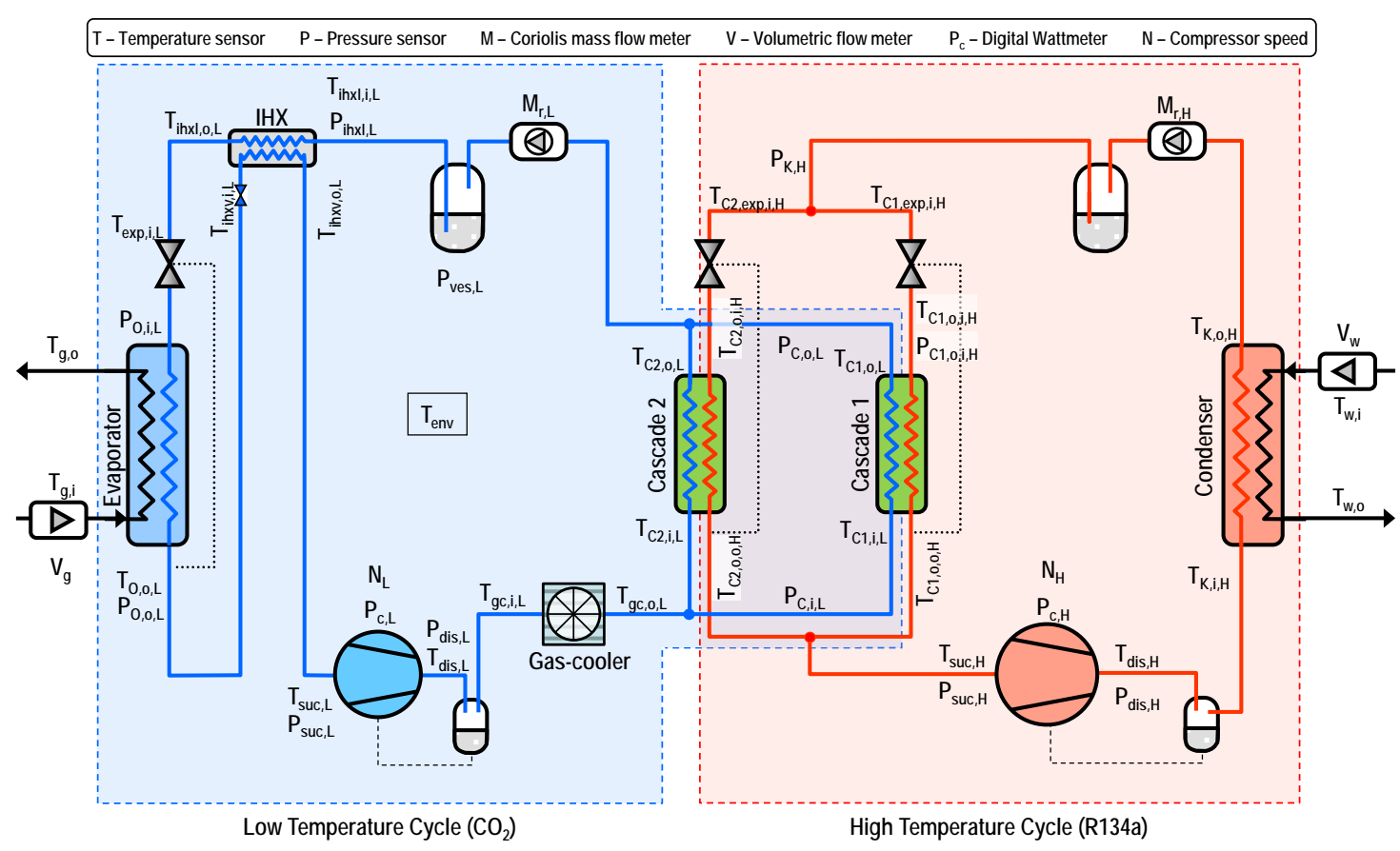

Figure 3. Schematic diagram of the experimental plant 


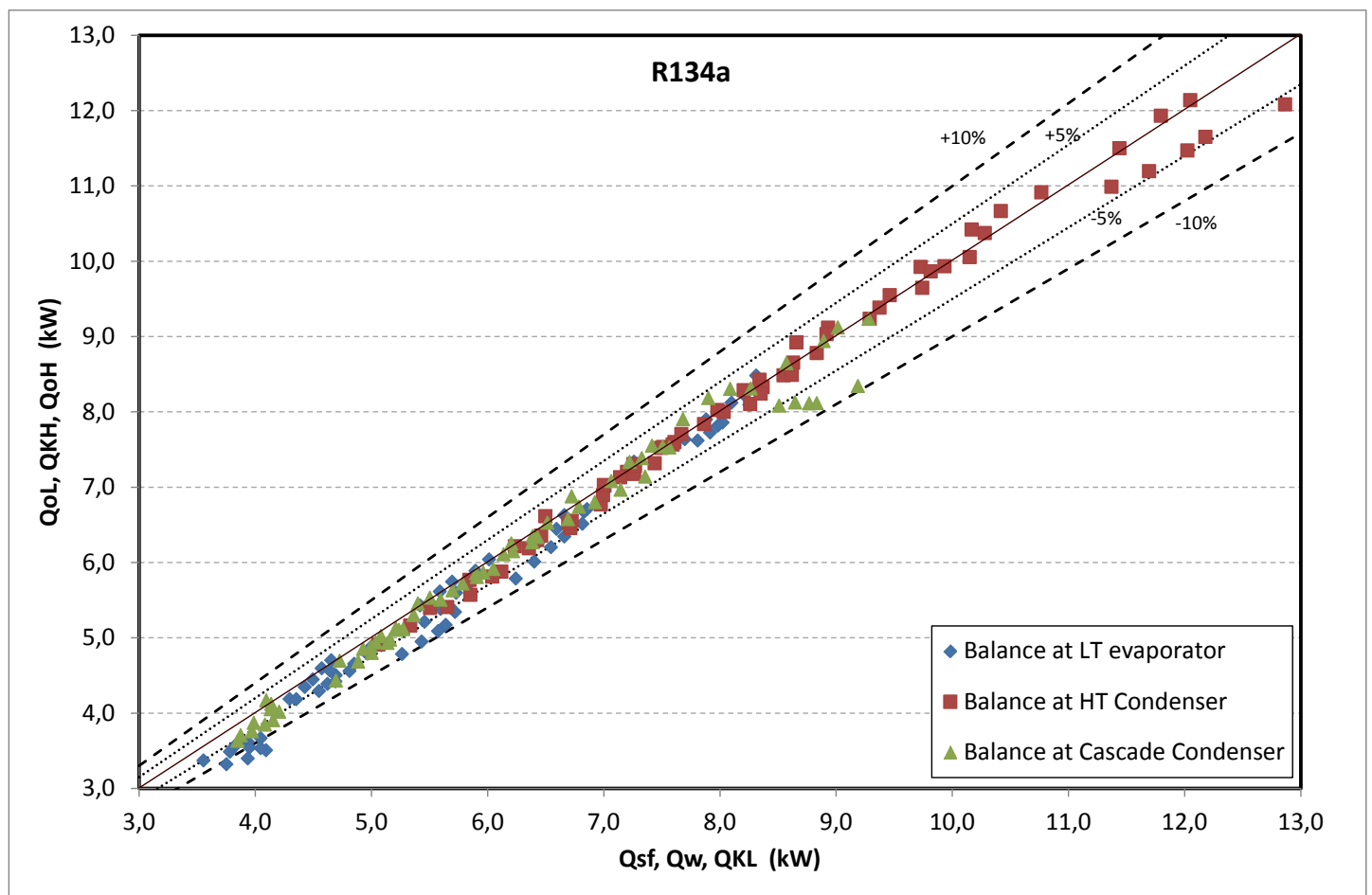

Figure 4a. Validation of heat transfer rates in the cascade plant using R134a/R744 


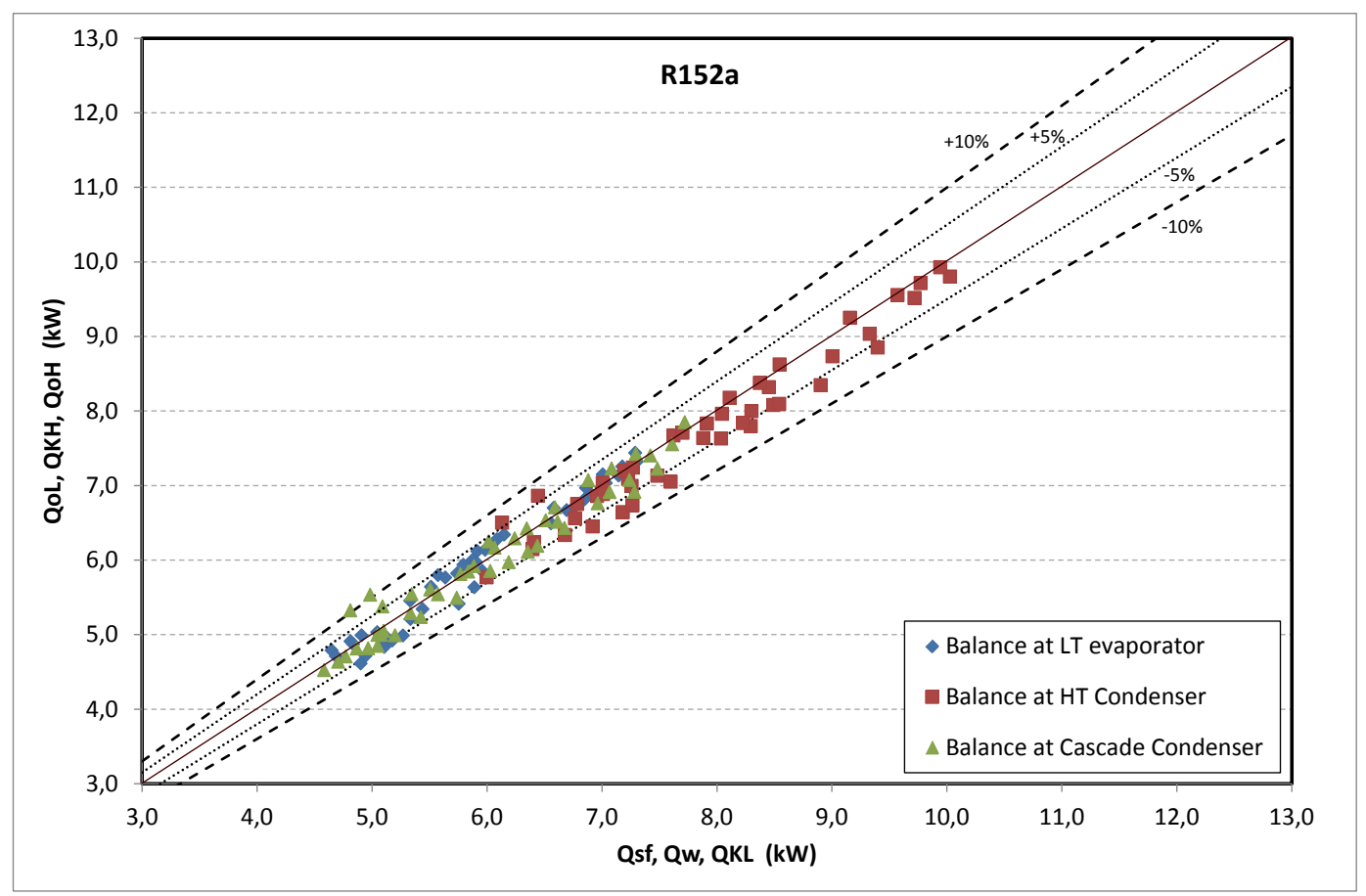

Figure 4b. Validation of heat transfer rates in the cascade plant using R152a/R744 

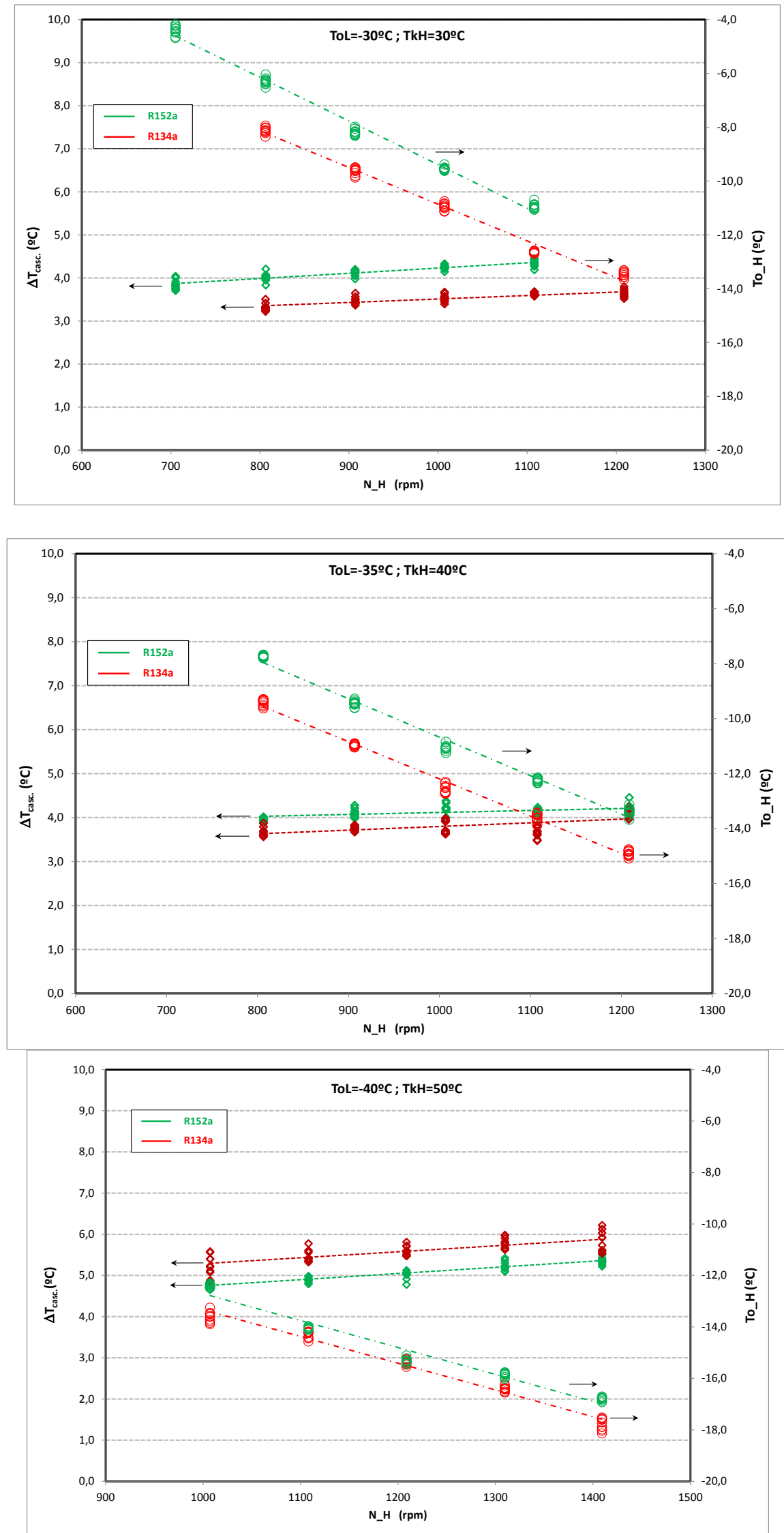

Figures $5 a, 5 b$ y $5 c . \Delta T_{\text {casc. }}$ y $T_{k L}$ con $T_{k H}, T_{\text {oL }}$ y $N_{H}$ evolution for different operating conditions 


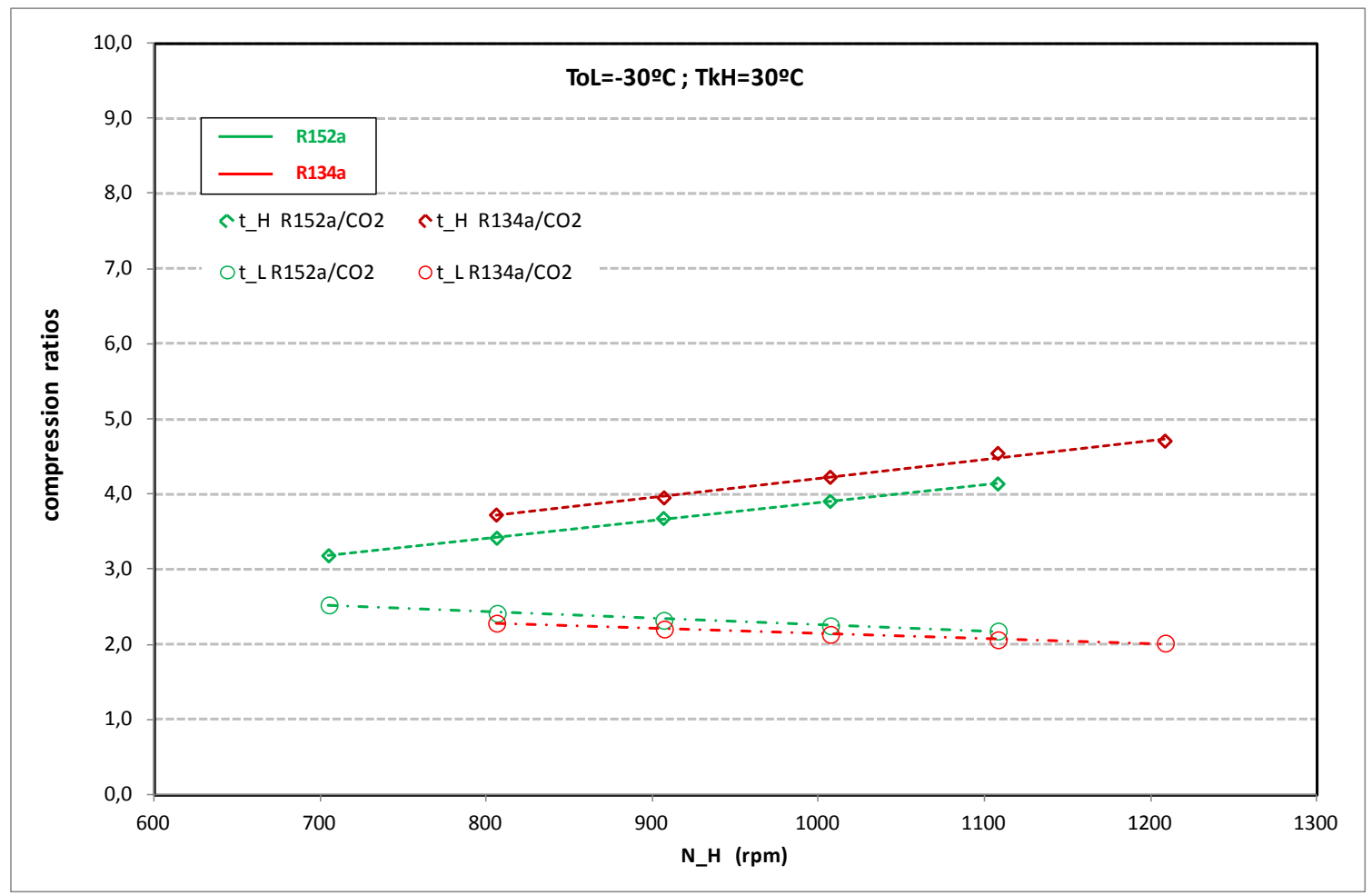

Figure 6a. Pressure Ratio in High and Low temperature cycles, working at $T o L=-30^{\circ} \mathrm{C}$ and $\mathrm{TkH}=30^{\circ} \mathrm{C}$ 


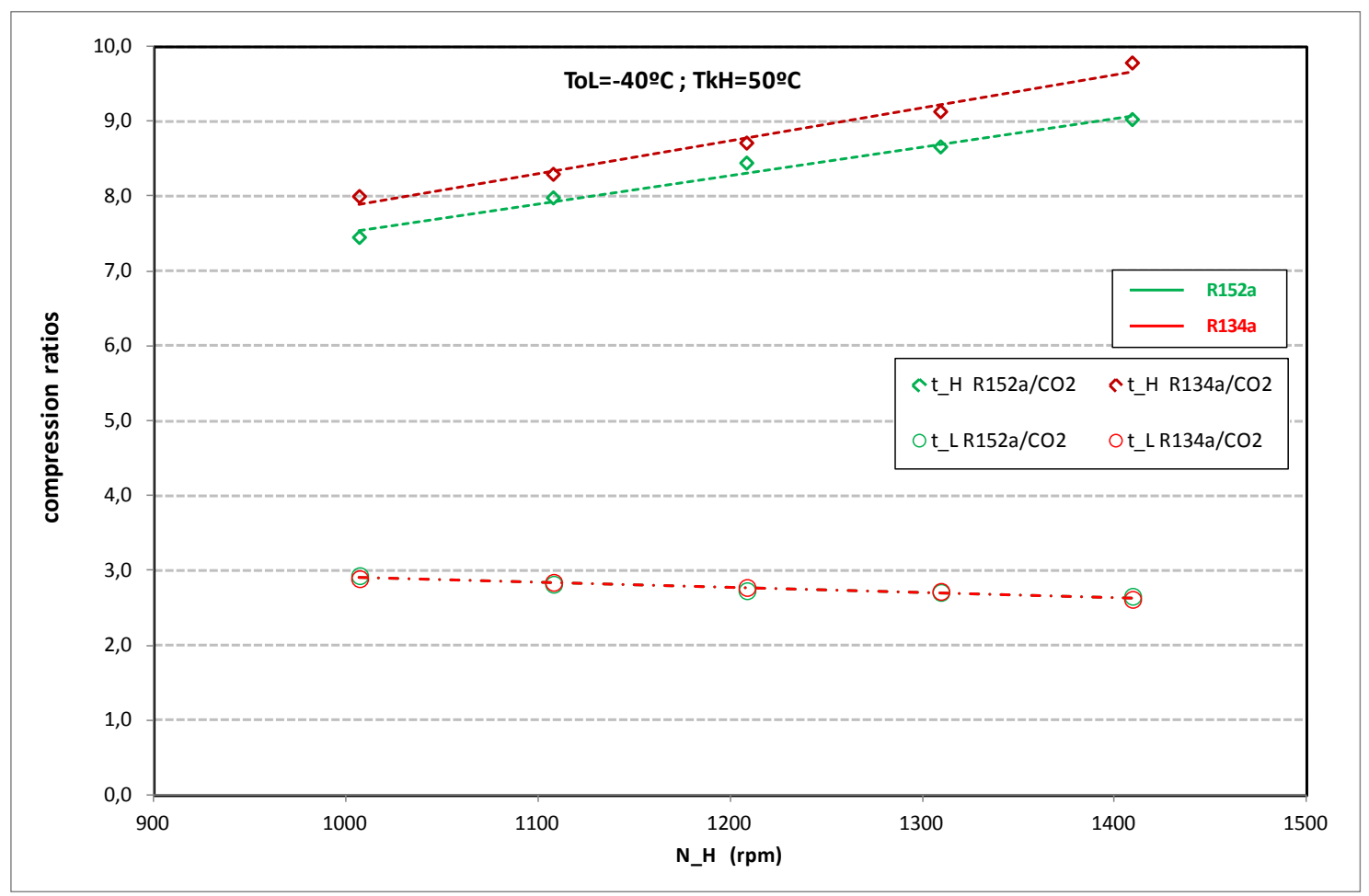

Figure 6b. Pressure ratio in High and Low temperature cycles, working at $\mathrm{ToL}=-40^{\circ} \mathrm{C}$ and $\mathrm{TkH}=50^{\circ} \mathrm{C}$ 


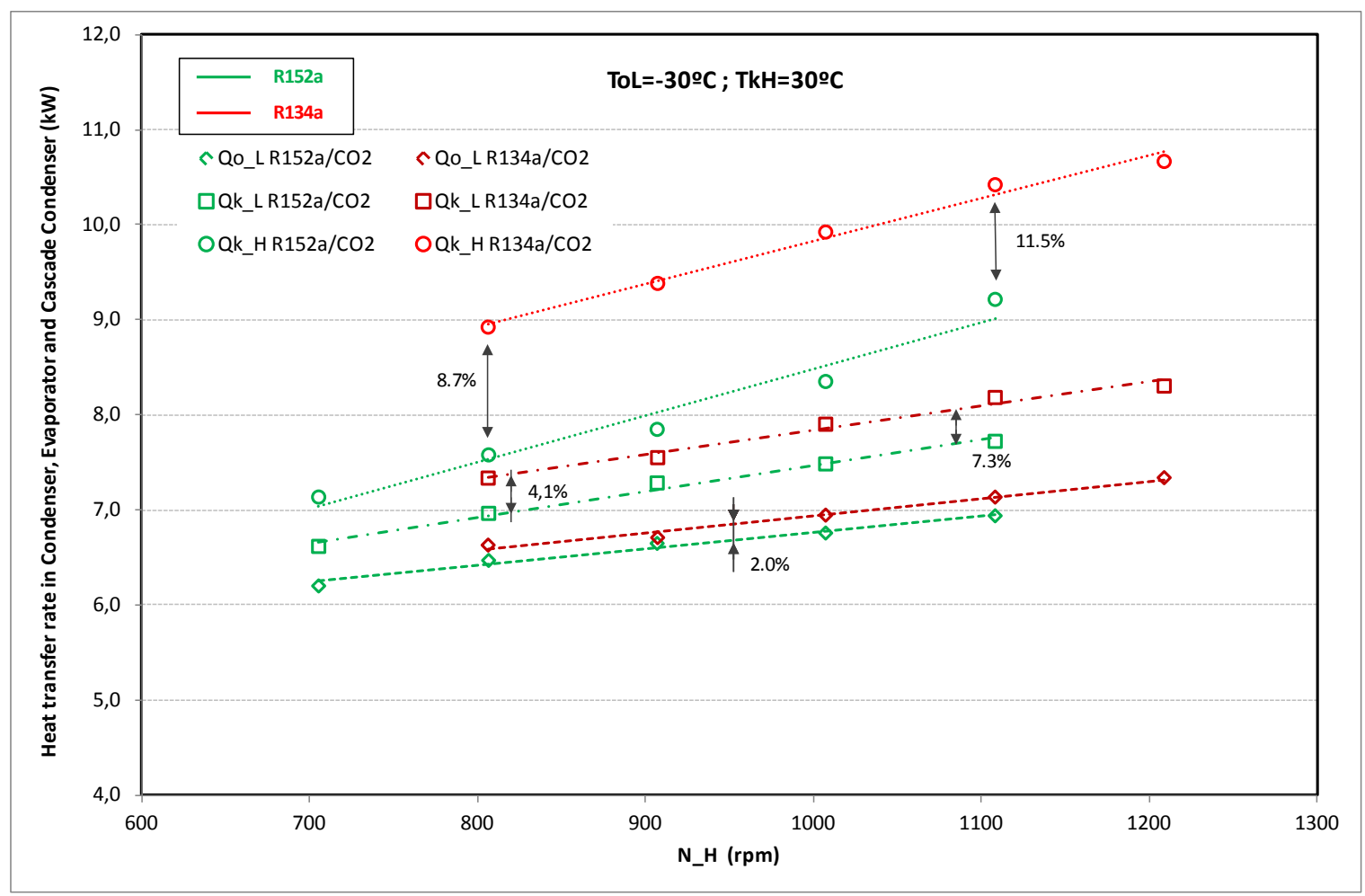

Figure 7a. Main Heat transfer rates in cascade refrigeration facility at $\mathrm{ToL}=-30^{\circ} \mathrm{C}$ and $\mathrm{TkH}=30^{\circ} \mathrm{C}$ 


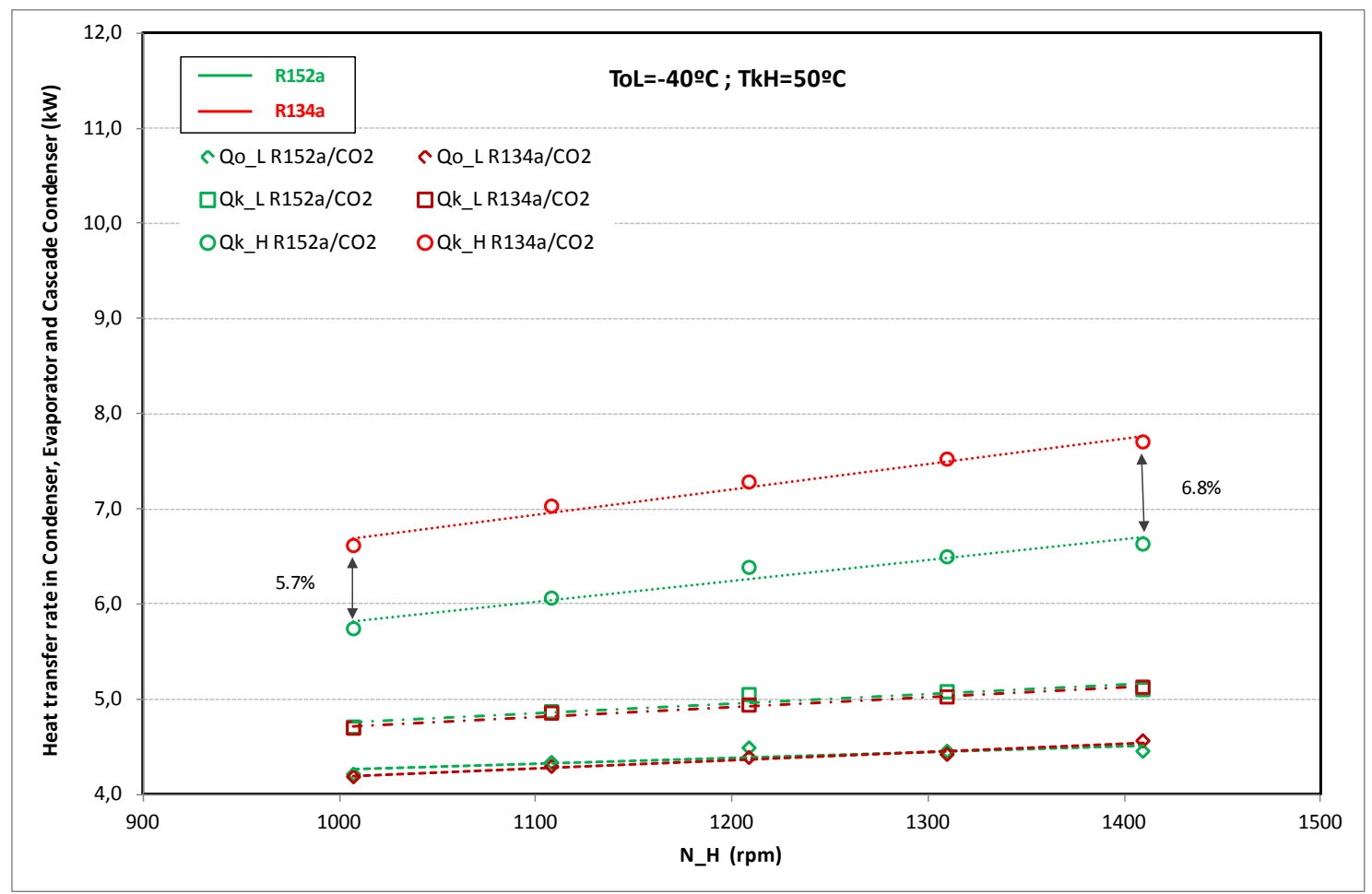

Figure $7 \mathrm{~b}$. Main Heat transfer rates in cascade refrigeration facility at $\mathrm{ToL}=-40^{\circ} \mathrm{C}$ and $\mathrm{TkH}=50^{\circ} \mathrm{C}$ 


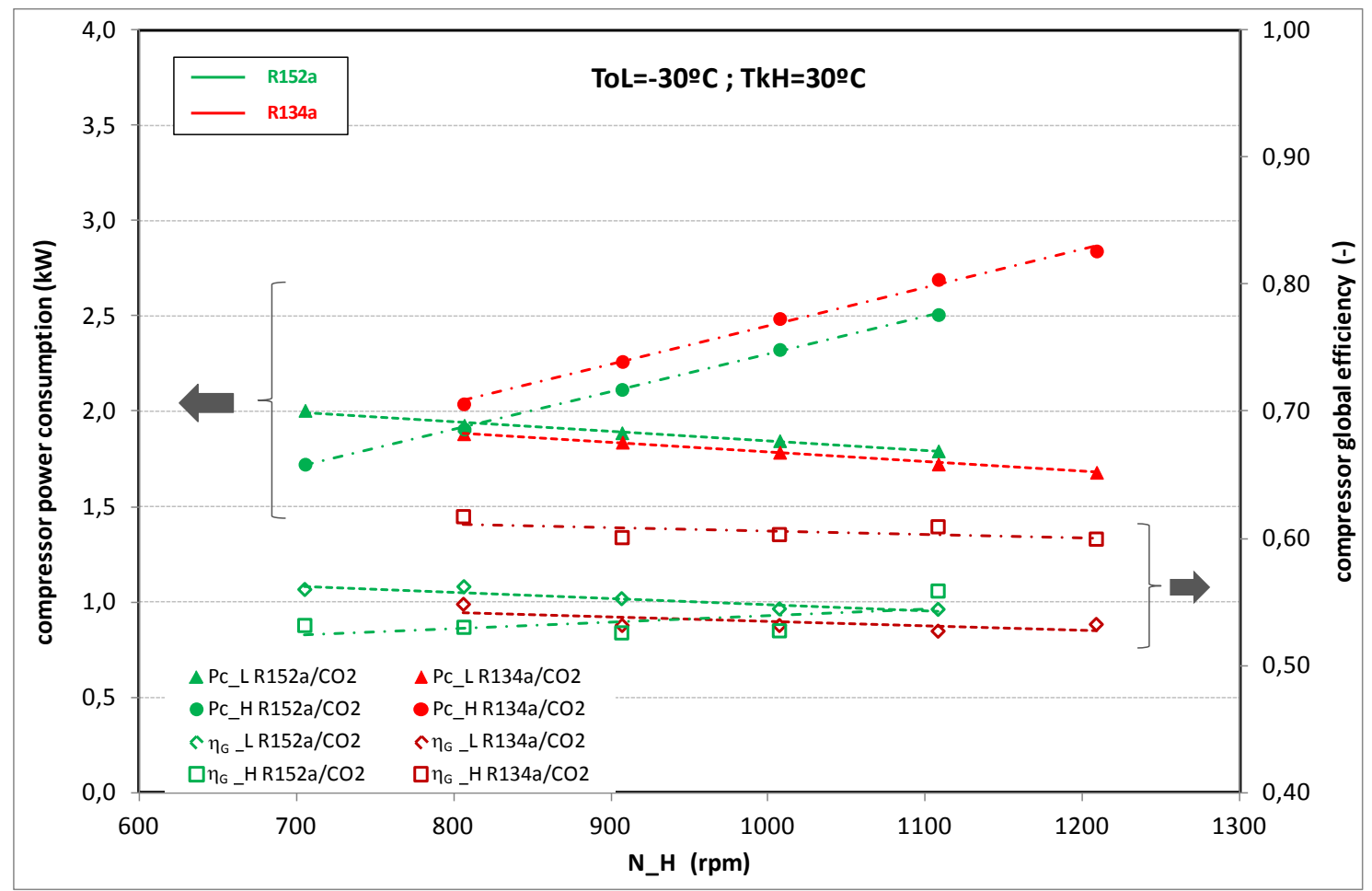

Figure $8 \mathrm{a}$ Compressors power consumption and global efficiency at $\mathrm{ToL}=-30^{\circ} \mathrm{C}$ and $\mathrm{TkH}=30^{\circ} \mathrm{C}$ 


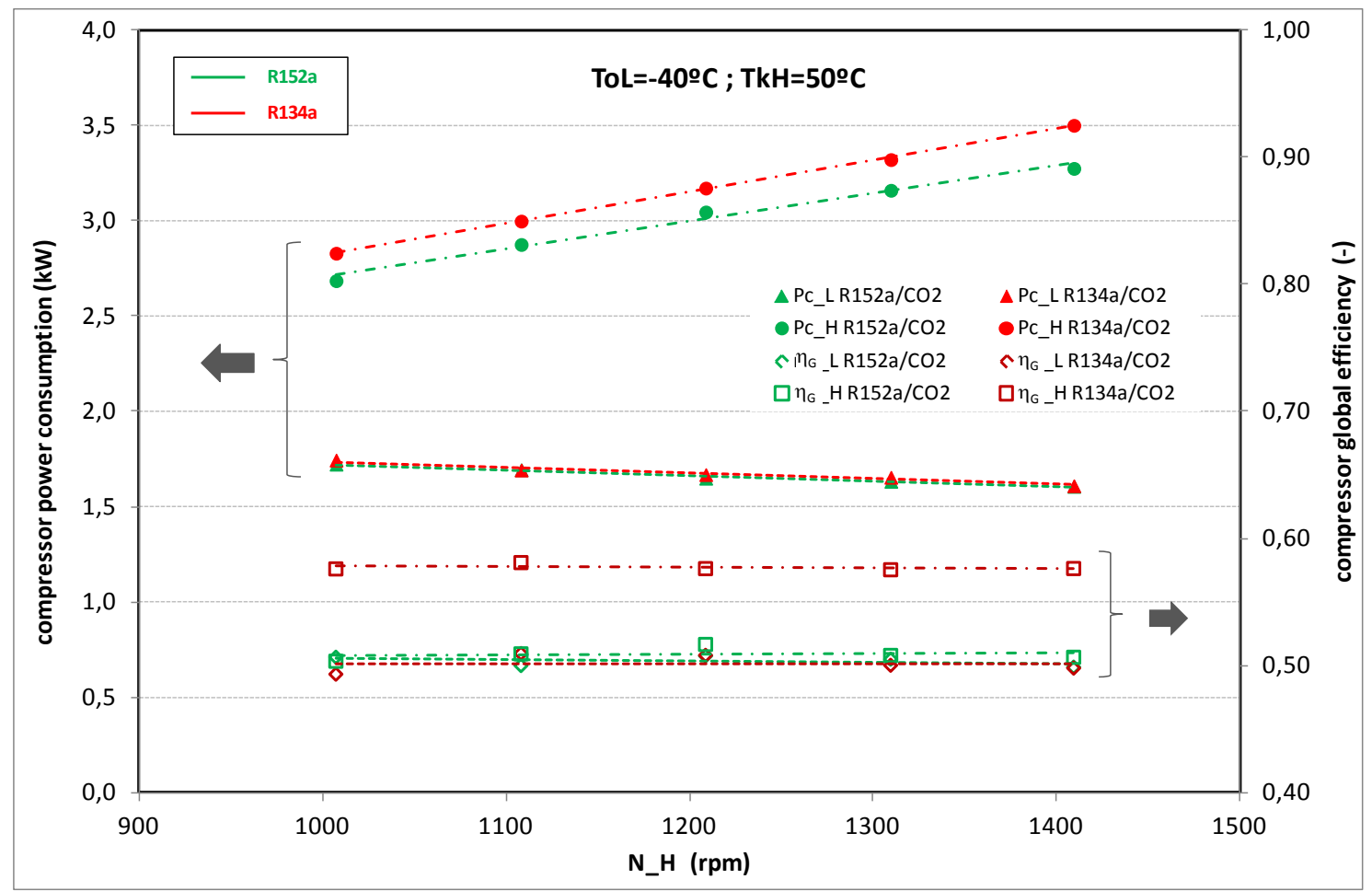

Figure $8 \mathrm{~b}$ Compressors power consumption and global efficiency at $\mathrm{ToL}=-40^{\circ} \mathrm{C}$ and $\mathrm{TkH}=50^{\circ} \mathrm{C}$ 

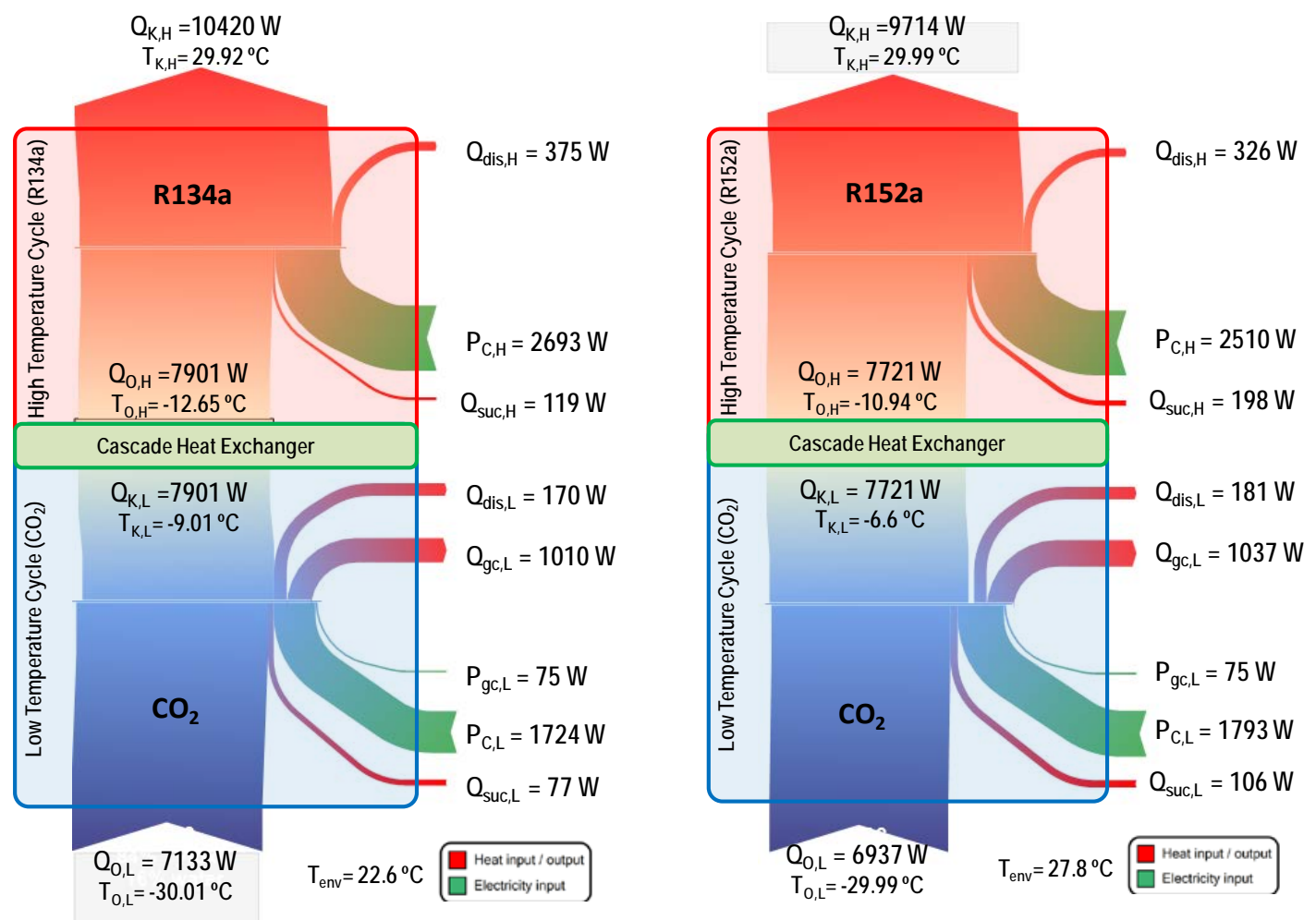

Figure 9. Energy flow through the cascade plant at $T_{O, L}=-30.0^{\circ} \mathrm{C}, T_{K, H}=30.0^{\circ} \mathrm{C}, N_{L}=1450 \mathrm{rpm}, \mathrm{N}_{H}=1108 \mathrm{rpm}$ 


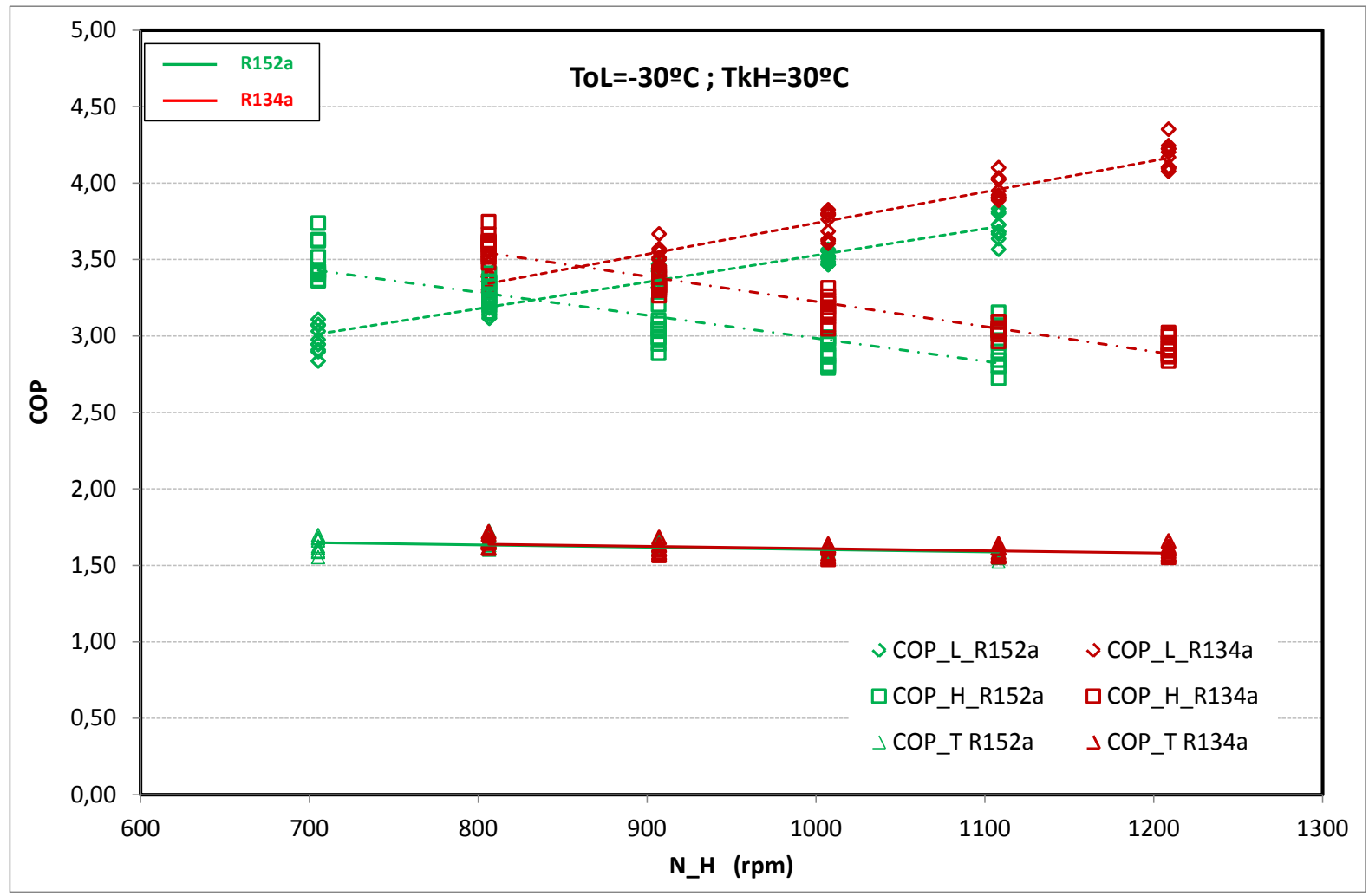

Figure 10a Energy Efficiency of the HT and LT cycles calculated separately $\left(\mathrm{COP}_{\mathrm{L}}\right.$ and $\left.\mathrm{COP}_{H}\right)$ and connected in cascade $\left(\mathrm{COP}_{\mathrm{T}}\right)$ at $\mathrm{ToL}=-30^{\circ} \mathrm{C}$ and $\mathrm{TkH}=30^{\circ} \mathrm{C}$ 


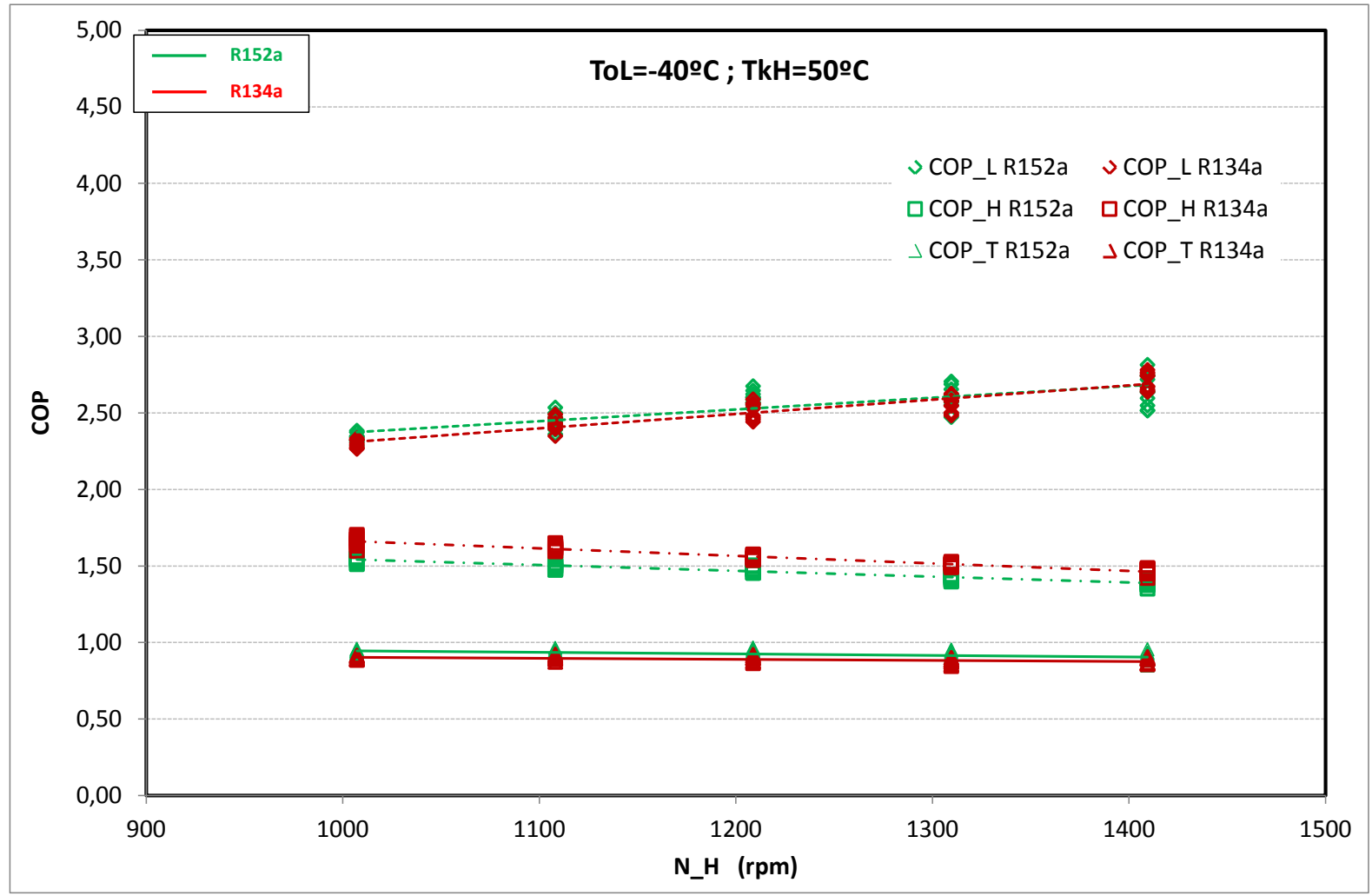

Figure 10b Energy Efficiency of the HT and LT cycles calculated separately $\left(\mathrm{COP}_{\mathrm{L}}\right.$ and $\left.\mathrm{COP}_{H}\right)$ and connected in cascade $\left(\mathrm{COP}_{\mathrm{T}}\right) \mathrm{ToL}=-40^{\circ} \mathrm{C}$ and $\mathrm{TkH}=50^{\circ} \mathrm{C}$ 


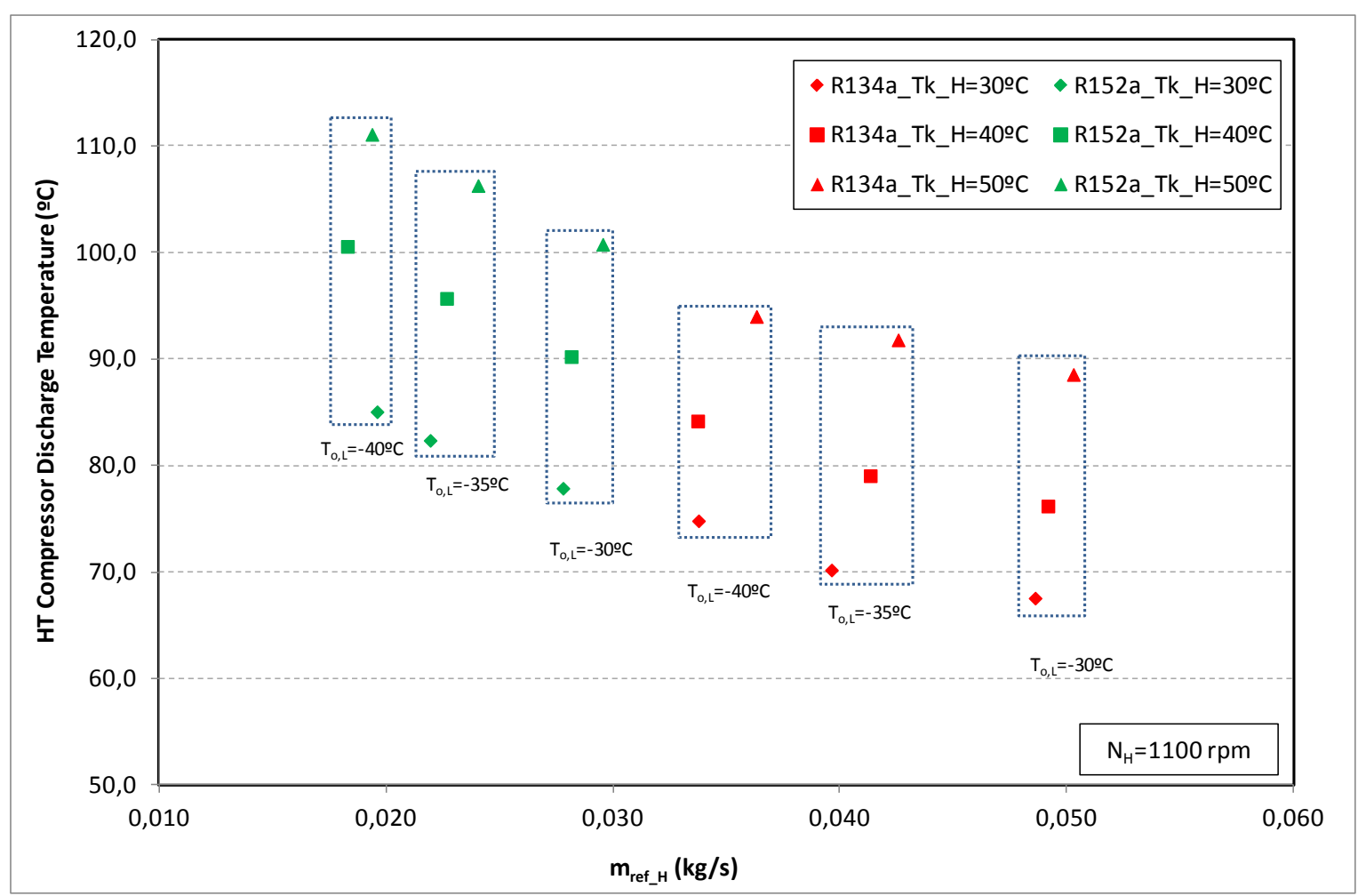

Figure 11. Compressor discharge temperatures versus refrigerant mass flow rate, both in HT cycle, when the compressor is running at $1100 \mathrm{rpm}$ in different operating conditions. 


\begin{tabular}{|c|c|c|c|c|c|c|c|c|c|c|c|c|}
\hline Fluid & $\begin{array}{c}\text { Chemical } \\
\text { formula }\end{array}$ & $\begin{array}{l}\begin{array}{l}P_{\text {crit }} \\
(\mathrm{MPa})\end{array} \\
\end{array}$ & $\begin{array}{l}\mathrm{T}_{\text {crit }} \\
\left({ }^{\circ} \mathrm{C}\right)\end{array}$ & $\begin{array}{c}\mathrm{MW} \\
\left(\mathrm{kg} \cdot \mathrm{kmol}^{-1}\right)\end{array}$ & $\begin{array}{l}\text { NBP } \\
\left({ }^{\circ} \mathrm{C}\right)\end{array}$ & $\begin{array}{c}V_{\text {sat, }} v^{*} \\
\left(m^{3} \cdot \mathrm{kg}^{-1}\right)\end{array}$ & $\begin{array}{c}\lambda^{*} \\
\left(\mathrm{~kJ} \cdot \mathrm{kg}^{-1}\right)\end{array}$ & $\begin{array}{c}q^{*} v^{*} \\
\left(k J \cdot m^{-3}\right)\end{array}$ & $\begin{array}{l}\text { Safety } \\
\text { Group }\end{array}$ & $\begin{array}{c}\mathrm{RCL} \\
\left(\mathrm{gr} \cdot \mathrm{m}^{-3}\right)\end{array}$ & $\begin{array}{c}\mathrm{HOC} \\
\left(\mathrm{MJ}^{\prime} \cdot \mathrm{kg}^{-1}\right)\end{array}$ & $\begin{array}{c}\text { GWP1 } \\
\text { WGI-AR51 }\end{array}$ \\
\hline R152a & $\mathrm{CH}_{3} \mathrm{CHF}_{2}$ & 4.52 & 113.26 & 66.051 & -24.02 & 0.296 & 329.91 & 1113.66 & A2 & 32 & 17,4 & 138 \\
\hline R134a & $\mathrm{CH}_{2} \mathrm{FCF}_{3}$ & 4.06 & 101.06 & 102.032 & -26.07 & 0.190 & 216.97 & 1140.81 & A1 & 210 & 4.2 & 1300 \\
\hline
\end{tabular}

1Working Group I contribution to the IPCC Fifth Assessment Report

$$
\text { *property calculated at NBP }
$$

Table 1 - Main thermodynamic, safety and environmental properties of R134a and R152a 


\begin{tabular}{|c|c|c|c|}
\hline \multicolumn{2}{|l|}{ High Temperature Cycle (HTC) } & \multicolumn{2}{|l|}{ Low Temperature Cycle (LTC) } \\
\hline \multirow{2}{*}{ Working Fluid } & HFC134a & Working Fluid & $\begin{array}{l}\mathrm{R} 744 \\
\left(\mathrm{CO}_{2}\right)\end{array}$ \\
\hline & HFC152a & Evaporating temperature $\mathrm{T}_{\mathrm{OL}}\left({ }^{\circ} \mathrm{C}\right)$ & -30 \\
\hline Condensing temperature $\mathrm{T}_{\mathrm{KH}}\left({ }^{\circ} \mathrm{C}\right)$ & 30 & Condensing temperature $T_{\mathrm{KL}}\left({ }^{\circ} \mathrm{C}\right)$ & -7 \\
\hline Superheat at evaporator outlet (K) & 5 & Superheat at evaporator outlet (K) & 5 \\
\hline Subcooling at expansion valve inlet (K) & 2 & Subcooling at expansion valve inlet $(\mathrm{K})$ & 2 \\
\hline Superheat at compressor suction (K) & 15 & Superheat at compressor suction (K) & 15 \\
\hline $\begin{array}{l}\text { Isentropic efficiency } \\
p_{k} / p_{o}\end{array}$ & $\eta_{i}=1-0,02$ & \multicolumn{2}{|l|}{$\begin{array}{l}\text { Isentropic efficiency } \\
p_{k} / p_{o}\end{array}$} \\
\hline $\begin{array}{l}\text { Volumetric efficiency } \\
p_{k} / p_{o}\end{array}$ & $\eta_{v}=1-0,02$ & $\begin{array}{l}\text { Volumetric efficiency } \\
p_{k} / p_{o}\end{array}$ & $\eta_{v}=1-0,04$ \\
\hline \multicolumn{4}{|c|}{ Refrigeration load : $\dot{Q}_{O L}=1 \mathrm{~kW}$} \\
\hline
\end{tabular}

Temperature difference in cascade condenser $\left(\Delta T_{\text {casc. }}\right): 5^{\circ} \mathrm{C}$

Table 2. Input data for theoretical simulation. 


\begin{tabular}{c|c|c|c}
\hline$q_{o}=h_{5}-h_{4}$ & Eq (1) & $q_{v}=\frac{q_{o}}{v_{1}}$ & Eq (2) \\
\hline$\dot{m}_{r e f, L}=\frac{\dot{Q}_{o, L}}{q_{o, L}}$ & Eq (3) & $\dot{m}_{r e f, H}=\frac{\dot{m}_{r e f, L} \cdot\left(h_{2 L}-h_{3 L}\right)}{q_{o, H}}$ & Eq (4) \\
\hline$\dot{V}_{G}=\frac{\dot{m}_{r e f} \cdot v_{1}}{\eta_{v}}$ & Eq (5) & $w_{c, s}=h_{2 s}-h_{1}$ & Eq (6) \\
\hline$w_{c}=\frac{h_{2 s}-h_{1}}{\eta_{i}}$ & Eq (7) & $P_{c}=\dot{m}_{r e f} \cdot w_{c}$ & Eq (8) \\
\hline$t=\frac{p_{k}}{p_{o}}$ & Eq (9) & $C O P_{L}=\frac{h_{5 L}-h_{4 L}}{h_{2 L}-h_{1 L}}$ & Eq (10) \\
\hline$C O P_{H}=\frac{h_{5 H}-h_{4 H}}{h_{2 H}-h_{1 H}}$ & Eq (11) & $=\frac{\dot{m}_{r e f, L} \cdot\left(h_{5 L}-h_{4 L}\right)}{\dot{m}_{r e f, L} \cdot\left(h_{2 L}-h_{1 L}\right)+\dot{m}_{r e f, H} \cdot\left(h_{2 H}-h_{1 H}\right)}$ & Eq (12) \\
\hline
\end{tabular}

Table 3. Equations used in theoretical simulation 


\begin{tabular}{|c|c|c|c|c|c|}
\hline \multicolumn{3}{|c|}{ Ciclo R152a } & \multicolumn{3}{|c|}{ Ciclo R134a } \\
\hline$\dot{m}_{r e f, H}$ & $(\mathrm{~kg} / \mathrm{s})$ & 0.0047 & $\dot{m}_{r e f, H}$ & $(\mathrm{~kg} / \mathrm{s})$ & 0.0076 \\
\hline$q_{0, H}$ & $(\mathrm{~kJ} / \mathrm{kg})$ & 254.7 & $q_{0, H}$ & $(\mathrm{~kJ} / \mathrm{kg})$ & 156.8 \\
\hline$q_{v, H}$ & $\left(\mathrm{~kJ} / \mathrm{m}^{3}\right)$ & 1264.4 & $q_{\mathrm{v}, \mathrm{H}}$ & $\left(\mathrm{kJ} / \mathrm{m}^{3}\right)$ & 1331.8 \\
\hline$\dot{V}_{G, H}$ & $\left(\mathrm{~m}^{3} / \mathrm{s}\right)$ & 0.00103 & $\dot{V}_{G, H}$ & $\left(\mathrm{~m}^{3} / \mathrm{s}\right)$ & 0.00098 \\
\hline$W_{c, S, H}$ & $(\mathrm{~kJ} / \mathrm{kg})$ & 51.3 & $W_{c, s, H}$ & $(\mathrm{~kJ} / \mathrm{kg})$ & 32.6 \\
\hline$W_{c, H}$ & $(\mathrm{~kJ} / \mathrm{kg})$ & 55.9 & $W_{c, H}$ & $(\mathrm{~kJ} / \mathrm{kg})$ & 35.5 \\
\hline $\mathrm{PC}, \mathrm{H}$ & $(W)$ & 263 & $\mathrm{PC}, \mathrm{H}$ & $(W)$ & 271 \\
\hline$T_{\text {dis }, H}$ & $\left(\mathrm{~K} /{ }^{\circ} \mathrm{C}\right)$ & $342.3 / 69.2$ & $T_{\text {dis }, H}$ & $\left(\mathrm{~K} /{ }^{\circ} \mathrm{C}\right)$ & $316.0 / 42.9$ \\
\hline$t_{H}$ & - & 4.11 & $t_{H}$ & - & 4.15 \\
\hline $\mathrm{COP}_{\mathrm{H}}$ & - & 3.6 & $\mathrm{COP}_{\mathrm{H}}$ & - & 3.3 \\
\hline \multicolumn{6}{|c|}{ Ciclo R744 } \\
\hline \multicolumn{2}{|c|}{$\dot{m}_{r e f, L}$} & \multicolumn{2}{|c|}{$(\mathrm{kg} / \mathrm{s})$} & \multicolumn{2}{|c|}{0.0037} \\
\hline \multicolumn{2}{|c|}{$q_{0, L}$} & \multicolumn{2}{|c|}{$(\mathrm{kJ} / \mathrm{kg})$} & \multicolumn{2}{|c|}{268.3} \\
\hline \multicolumn{2}{|c|}{$q_{v, L}$} & \multicolumn{2}{|c|}{$\left(\mathrm{kJ} / \mathrm{m}^{3}\right)$} & \multicolumn{2}{|c|}{8738.9} \\
\hline \multicolumn{2}{|c|}{$\dot{V}_{G, L}$} & \multicolumn{2}{|c|}{$\left(\mathrm{m}^{3} / \mathrm{s}\right)$} & \multicolumn{2}{|c|}{0.00012} \\
\hline \multicolumn{2}{|c|}{$W_{c, S, L}$} & \multicolumn{2}{|c|}{$(\mathrm{kJ} / \mathrm{kg})$} & \multicolumn{2}{|c|}{33.3} \\
\hline \multicolumn{2}{|c|}{$W_{c, L}$} & \multicolumn{2}{|c|}{$(\mathrm{kJ} / \mathrm{kg})$} & \multicolumn{2}{|c|}{37.6} \\
\hline \multicolumn{2}{|c|}{$\mathrm{PC}, \mathrm{L}$} & \multicolumn{2}{|c|}{$(W)$} & \multicolumn{2}{|c|}{140} \\
\hline \multicolumn{2}{|c|}{$\mathrm{T}_{\text {dis }, \mathrm{L}}$} & \multicolumn{2}{|c|}{$\left(\mathrm{K} /{ }^{\circ} \mathrm{C}\right)$} & \multicolumn{2}{|c|}{$316.6 / 42.9$} \\
\hline \multicolumn{2}{|c|}{$t_{L}$} & \multicolumn{2}{|c|}{-} & \multicolumn{2}{|c|}{2.40} \\
\hline \multicolumn{2}{|c|}{$\mathrm{COP}$} & \multicolumn{2}{|c|}{-} & \multicolumn{2}{|c|}{5.0} \\
\hline $\mathrm{COP}_{\mathrm{T}}$ & $\left.\mathrm{R} 152 \mathrm{a} / \mathrm{CO}_{2}\right)$ & 2.480 & $\mathrm{COP}_{\mathrm{T}}$ & (R134a/C & 2.430 \\
\hline
\end{tabular}

Table 4. Energy parameters calculated 


\begin{tabular}{|c|c|c|c|c|c|c|c|c|c|}
\hline $\begin{array}{l}\mathrm{T}_{0, \mathrm{~L}} \\
\left({ }^{\circ} \mathrm{C}\right)\end{array}$ & $\begin{array}{l}\mathrm{T}_{\mathrm{K}, \mathrm{L}} \\
\left({ }^{\circ} \mathrm{C}\right)\end{array}$ & $\begin{array}{c}\Delta \mathrm{T}_{\mathrm{SH}, \mathrm{L}} \\
\left({ }^{\circ} \mathrm{C}\right)\end{array}$ & $\begin{array}{c}\mathrm{N}_{\mathrm{L}} \\
\text { (rpm) }\end{array}$ & $\begin{array}{l}\mathrm{T}_{0, \mathrm{H}} \\
\left({ }^{\circ} \mathrm{C}\right)\end{array}$ & $\begin{array}{l}\mathrm{T}_{\mathrm{K}, \mathrm{H}} \\
\left({ }^{\circ} \mathrm{C}\right)\end{array}$ & $\begin{array}{c}\Delta \mathrm{T}_{\mathrm{SH}, \mathrm{H}} \\
\left({ }^{\circ} \mathrm{C}\right)\end{array}$ & $\begin{array}{l}\mathrm{T}_{\text {env }} \\
\left({ }^{\circ} \mathrm{C}\right)\end{array}$ & $\begin{array}{c}\mathrm{N}_{\mathrm{H}} \\
\text { (rpm) }\end{array}$ & $\begin{array}{l}\text { Steady- } \\
\text { states }\end{array}$ \\
\hline$-30 \pm 0.1$ & -6.6 to -0.6 & $9.3 \pm 0.2$ & 1450 & -10.9 to -4.4 & $30 \pm 0.1$ & $7.4 \pm 0.2$ & $27.5 \pm 1$ & 705 to 1108 & 5 \\
\hline$-35 \pm 0.1$ & -10.7 to -5.3 & $9.3 \pm 0.1$ & 1450 & -15.7 to -9.9 & $30 \pm 0.1$ & $7.7 \pm 0.3$ & $26.2 \pm 1.8$ & 806 to 1209 & 5 \\
\hline$-40 \pm 0.1$ & -13.2 to -7.9 & $9.3 \pm 0.1$ & 1450 & -19.3 to -13.6 & $30 \pm 0.1$ & $8.4 \pm 0.3$ & $27.1 \pm 1.5$ & 806 to 1209 & 5 \\
\hline$-30 \pm 0.1$ & -6.1 to -1.6 & $9.2 \pm 0.2$ & 1450 & -9.6 to -4.2 & $40 \pm 0.1$ & $7.4 \pm 0.5$ & $29.9 \pm 2$ & 806 to 1209 & 5 \\
\hline$-35 \pm 0.1$ & -9.2 to -3.8 & $9.2 \pm 0.1$ & 1450 & -13.4 to -7.7 & $40 \pm 0.1$ & $7.6 \pm 0.3$ & $30.0 \pm 1.3$ & 806 to 1209 & 5 \\
\hline$-40 \pm 0.1$ & -12.1 to -7.0 & $9.2 \pm 0.1$ & 1450 & -17.6 to -11.7 & $40 \pm 0.1$ & $7.8 \pm 0.3$ & $29.1 \pm 1.6$ & 806 to 1209 & 5 \\
\hline$-30 \pm 0.1$ & -4.6 to 0.9 & $9.1 \pm 0.1$ & 1450 & -7.8 to -2.0 & $50 \pm 0.1$ & $7.4 \pm 0.2$ & $28.0 \pm 1.2$ & 806 to 1209 & 5 \\
\hline$-35 \pm 0.1$ & -7.6 to -2.2 & $9.1 \pm 0.1$ & 1450 & -11.6 to -5.7 & $50 \pm 0.1$ & $7.6 \pm 0.2$ & $26.7 \pm 1.0$ & 806 to 1209 & 5 \\
\hline$-40 \pm 0.1$ & -11.4 to -7.6 & $9.1 \pm 0.1$ & 1450 & 16.8 to -12.4 & $50 \pm 0.1$ & $7.9 \pm 0.2$ & $27.9 \pm 1.2$ & 1007 to 1409 & 5 \\
\hline
\end{tabular}

Table 5a. Summary of the operating conditions kept during tests done with cascade refrigeration plant using R152a 


\begin{tabular}{cccccccccc}
\hline $\begin{array}{c}\mathrm{T}_{\mathrm{O}, \mathrm{L}} \\
\left({ }^{\circ} \mathrm{C}\right)\end{array}$ & $\begin{array}{c}\mathrm{T}_{\mathrm{K}, \mathrm{L}} \\
\left({ }^{\circ} \mathrm{C}\right)\end{array}$ & $\begin{array}{c}\Delta \mathrm{TSH}_{\mathrm{L}, \mathrm{L}} \\
\left({ }^{\circ} \mathrm{C}\right)\end{array}$ & $\begin{array}{c}\mathrm{N}_{\mathrm{L}} \\
(\mathrm{rpm})\end{array}$ & $\begin{array}{c}\mathrm{T}_{\mathrm{O}, \mathrm{H}} \\
\left({ }^{\circ} \mathrm{C}\right)\end{array}$ & $\begin{array}{c}\mathrm{T}_{\mathrm{K}, \mathrm{H}} \\
\left({ }^{\circ} \mathrm{C}\right)\end{array}$ & $\begin{array}{c}\Delta \mathrm{T}_{\mathrm{SH}, \mathrm{H}} \\
\left({ }^{\circ} \mathrm{C}\right)\end{array}$ & $\begin{array}{c}\mathrm{T}_{\text {env }} \\
\left({ }^{\circ} \mathrm{C}\right)\end{array}$ & $\begin{array}{c}\mathrm{N}_{\mathrm{H}} \\
(\mathrm{rpm})\end{array}$ & $\begin{array}{c}\text { Steady- } \\
\text { states }\end{array}$ \\
\hline$-30 \pm 0.1$ & --4.9 to 0.2 & $9.0 \pm 0.2$ & 1450 & -9.17 to -3.43 & $30 \pm 0.1$ & $8.7 \pm 0.8$ & $27.5 \pm 1.6$ & 907 to 1310 & 5 \\
$-35 \pm 0.1$ & -6.7 to -0.3 & $9.0 \pm 0.2$ & 1450 & -11.29 to -3.50 & $30 \pm 0.1$ & $10.0 \pm 0.5$ & $26.6 \pm 0.9$ & 705 to 1209 & 5 \\
$-40 \pm 0.1$ & -11.5 to -4.8 & $9.0 \pm 0.2$ & 1450 & -17.10 to -9.52 & $30 \pm 0.1$ & $9.5 \pm 1.8$ & $24.3 \pm 1.3$ & 806 to 1409 & 5 \\
$-30 \pm 0.1$ & -6.9 to -1.6 & $9.4 \pm 0.4$ & 1450 & -10.68 to -5.00 & $40 \pm 0.1$ & $9.5 \pm 0.6$ & $21.8 \pm 1.3$ & 806 to 1209 & 5 \\
$-35 \pm 0.1$ & -11.0 to -6.3 & $9.3 \pm 0.3$ & 1450 & -15.29 to -10.28 & $40 \pm 0.1$ & $9.4 \pm 0.5$ & $21.4 \pm 1.4$ & 907 to 1310 & 5 \\
$-40 \pm 0.1$ & -12.8 to -8.0 & $9.3 \pm 0.1$ & 1450 & -17.96 to -12.49 & $40 \pm 0.1$ & $9.6 \pm 0.4$ & $20.7 \pm 0.7$ & 806 to 1209 & 5 \\
$-30 \pm 0.1$ & -9.2 to -3.8 & $9.3 \pm 1.1$ & 1450 & -12.71 to -7.25 & $50 \pm 0.1$ & $10.5 \pm 1.2$ & $22.7 \pm 0.7$ & 806 to 1209 & 5 \\
$-35 \pm 0.1$ & -12.2 to -7.2 & $9.5 \pm 0.4$ & 1450 & -16.03 to -10.57 & $50 \pm 0.1$ & $9.7 \pm 1.1$ & $20.9 \pm 1.4$ & 806 to 1209 & 5 \\
$-40 \pm 0.1$ & -15.4 to -10.3 & $9.4 \pm 0.1$ & 1450 & -20.15 to -14.43 & $50 \pm 0.1$ & $9.4 \pm 0.9$ & $20.0 \pm 1.1$ & 806 to 12097 & 5
\end{tabular}

Table 5b. Summary of the operating conditions kept during tests done with cascade refrigeration plant using R134a 


\begin{tabular}{|c|c|c|c|c|c|c|c|c|c|c|c|c|c|c|c|c|c|c|c|}
\hline \multirow[t]{2}{*}{$\begin{array}{l}\mathrm{T}_{\mathrm{kH}} \\
\left({ }^{\circ} \mathrm{C}\right)\end{array}$} & \multirow[t]{2}{*}{$\begin{array}{l}\mathrm{T}_{\mathrm{OL}} \\
\left({ }^{\circ} \mathrm{C}\right)\end{array}$} & \multicolumn{2}{|c|}{$\begin{array}{l}\mathrm{T}_{\mathrm{kL}} \\
\left({ }^{\circ} \mathrm{C}\right)\end{array}$} & \multicolumn{2}{|c|}{$\begin{array}{c}\Delta \mathrm{T}_{\text {casc }} \\
\left({ }^{\circ} \mathrm{C}\right)\end{array}$} & \multicolumn{2}{|c|}{$\begin{array}{c}\dot{m}_{\text {ref.L }} \\
\text { (kg/s) }\end{array}$} & \multicolumn{2}{|c|}{$\begin{array}{c}\dot{m}_{\text {ref.H }} \\
\text { (kg/s) }\end{array}$} & \multicolumn{2}{|c|}{$\begin{array}{l}\dot{Q}_{o . L} \\
(\mathrm{~kW})\end{array}$} & \multicolumn{2}{|c|}{$\begin{array}{l}P_{c T} \\
(k W)\end{array}$} & \multicolumn{2}{|c|}{$\begin{array}{c}\mathrm{COP}_{\mathrm{T}} \\
(-)\end{array}$} & \multicolumn{2}{|c|}{$\begin{array}{l}\mathrm{T}_{\text {disc.H }} \\
\left({ }^{\circ} \mathrm{C}\right)\end{array}$} & \multicolumn{2}{|c|}{$\begin{array}{c}\mathrm{T}_{\text {disc. L }} \\
\left({ }^{\circ} \mathrm{C}\right)\end{array}$} \\
\hline & & $\begin{array}{c}\mathrm{CO2} \\
\text { (R134a) }\end{array}$ & $\begin{array}{c}\mathrm{CO2} \\
\text { (R152a) }\end{array}$ & R134a & R152a & $\begin{array}{c}\mathrm{CO} 2 \\
\text { (R134a) }\end{array}$ & $\begin{array}{c}\mathrm{CO} 2 \\
\text { (R152a) }\end{array}$ & R134a & R152a & $\begin{array}{c}\mathrm{CO} \\
\text { (R134a) }\end{array}$ & $\begin{array}{c}\mathrm{CO} \\
\text { (R152a) }\end{array}$ & R134a & R152a & $\begin{array}{c}\text { R134al } \\
\mathrm{CO} 2\end{array}$ & $\begin{array}{l}\text { R152al } \\
\text { CO2 }\end{array}$ & R134a & R152a & $\begin{array}{c}\mathrm{CO2} \\
\text { (R134a) }\end{array}$ & $\begin{array}{c}\mathrm{CO2} \\
\text { (R152a) }\end{array}$ \\
\hline 30.00 & -30.00 & -9.0 & -6.6 & 3.6 & 4.3 & 0.02655 & 0.0260 & 0.0486 & 0.0278 & 7.134 & 6.937 & 4.492 & 4.38 & 1.588 & 1.585 & 67.6 & 77.9 & 65.2 & 73.8 \\
\hline 30.00 & -35.00 & -11.9 & -9.8 & 3.7 & 4.9 & 0.02148 & 0.0212 & 0.0396 & 0.0219 & 5.889 & 5.778 & 4.217 & 4.15 & 1.397 & 1.392 & 70.2 & 82.4 & 73.1 & 81.2 \\
\hline 30.00 & -40.00 & -14.5 & -12.2 & 4.6 & 6.0 & 0.01724 & 0.0170 & 0.0338 & 0.0196 & 4.802 & 4.708 & 3.964 & 3.93 & 1.211 & $1.198 x$ & 74.8 & 85.1 & 83.2 & 94.1 \\
\hline 40.00 & -30.00 & -6.7 & -5.4 & 3.6 & 3.4 & 0.02597 & 0.0253 & 0.0492 & 0.0282 & 6.831 & 6.690 & 4.914 & 4.82 & 1.390 & 1.388 & 76.2 & 90.2 & 71.7 & 78.3 \\
\hline 40.00 & -35.00 & -9.9 & -8.1 & 3.7 & 4.1 & 0.02112 & 0.0204 & 0.0413 & 0.0227 & 5.699 & 5.502 & 4.624 & 4.51 & 1.232 & 1.219 & 79.1 & 95.7 & 77.8 & 88.7 \\
\hline 40.00 & -40.00 & -12.4 & -10.5 & 5.0 & 5.3 & 0.01677 & 0.0162 & 0.0337 & 0.0183 & 4.593 & 4.418 & 4.328 & 4.23 & 1.061 & 1.044 & 84.2 & 100.6 & 92.0 & 101.2 \\
\hline 50.00 & -30.00 & -3.3 & -3.3 & 4.1 & 3.1 & 0.02486 & 0.0247 & 0.0503 & 0.0295 & 6.345 & 6.472 & 5.472 & 5.29 & 1.160 & 1.223 & 88.6 & 100.8 & 85.7 & 85.1 \\
\hline 50.00 & -35.00 & -6.1 & -6.2 & 4.8 & 3.9 & 0.01986 & 0.0199 & 0.0426 & 0.0240 & 5.171 & 5.320 & 5.138 & 4.93 & 1.007 & 1.080 & 91.8 & 106.3 & 95.7 & 95.7 \\
\hline 50.00 & -40.00 & -8.8 & -9.2 & 5.5 & 4.9 & 0.01616 & 0.0160 & 0.0363 & 0.0194 & 4.292 & 4.333 & 4.766 & 4.65 & 0.901 & 0.933 & 94.0 & 111.1 & 105.3 & 106.2 \\
\hline
\end{tabular}

Table 6a. Data summary of the tests carried out at the compressors speeds: $N_{L}=1450 \mathrm{rpm}$ and $\mathrm{N}_{H}=1108 \mathrm{rpm}$ 


\begin{tabular}{|c|c|c|c|c|c|c|c|c|c|c|c|c|c|c|c|c|c|c|c|}
\hline \multirow[t]{2}{*}{$\begin{array}{l}\mathrm{T}_{\mathrm{kH}} \\
\left({ }^{\circ} \mathrm{C}\right)\end{array}$} & \multirow[t]{2}{*}{$\begin{array}{l}\mathrm{T}_{\mathrm{oL}} \\
\left({ }^{\circ} \mathrm{C}\right)\end{array}$} & \multicolumn{2}{|c|}{$\begin{array}{l}\mathrm{T}_{\mathrm{kL}} \\
\left({ }^{\circ} \mathrm{C}\right)\end{array}$} & \multicolumn{2}{|c|}{$\begin{array}{c}\Delta \mathrm{T}_{\text {casc }} \\
\left({ }^{\circ} \mathrm{C}\right)\end{array}$} & \multicolumn{2}{|c|}{$\begin{array}{c}\dot{m}_{\text {ref.L }} \\
\text { (kg/s) }\end{array}$} & \multicolumn{2}{|c|}{$\begin{array}{c}\dot{m}_{\text {ref.H }} \\
\text { (kg/s) }\end{array}$} & \multicolumn{2}{|c|}{$\begin{array}{l}\dot{Q}_{o . L} \\
(\mathrm{~kW})\end{array}$} & \multicolumn{2}{|c|}{$\begin{array}{c}P_{\mathrm{cT}} \\
(\mathrm{kW})\end{array}$} & \multicolumn{2}{|c|}{$\begin{array}{c}\mathrm{COP}_{\mathrm{T}} \\
(-)\end{array}$} & \multicolumn{2}{|c|}{$\begin{array}{c}\mathrm{T}_{\text {disc. } \mathrm{H}} \\
\left({ }^{\circ} \mathrm{C}\right)\end{array}$} & \multicolumn{2}{|c|}{$\begin{array}{c}\mathrm{T}_{\text {disc.L }} \\
\left({ }^{\circ} \mathrm{C}\right)\end{array}$} \\
\hline & & $\begin{array}{c}\mathrm{CO2} \\
\text { (R134a) }\end{array}$ & $\begin{array}{c}\mathrm{CO2} \\
\text { (R152a) }\end{array}$ & R134a & R152a & $\begin{array}{c}\mathrm{CO2} \\
\text { (R134a) }\end{array}$ & $\begin{array}{c}\mathrm{CO} \\
\text { (R152a) }\end{array}$ & R134a & R152a & $\begin{array}{c}\mathrm{CO2} \\
\text { (R134a) }\end{array}$ & $\begin{array}{c}\mathrm{CO} 2 \\
\text { (R152a) }\end{array}$ & R134a & R152a & $\begin{array}{c}\text { R134al } \\
\text { CO2 }\end{array}$ & $\begin{array}{c}\text { R152al } \\
\text { CO2 }\end{array}$ & R134a & R152a & $\begin{array}{c}\mathrm{CO2} \\
\text { (R134a) }\end{array}$ & $\begin{array}{c}\mathrm{CO2} \\
\text { (R152a) }\end{array}$ \\
\hline 30.00 & -30.00 & -7.4 & -5.3 & 3.5 & 4.2 & 0.0262 & 0.0255 & 0.0468 & 0.0254 & 6.9 & 6.8 & 4.35 & 4.25 & 1.597 & 1.591 & 65.7 & 75.4 & 70.0 & 78.9 \\
\hline 30.00 & -35.00 & -10.9 & -8.3 & 3.7 & 4.9 & 0.0211 & 0.0207 & 0.0380 & 0.0222 & 5.7 & 5.6 & 4.10 & 4.02 & 1.401 & 1.397 & 69.2 & 80.0 & 77.9 & 87.1 \\
\hline 30.00 & -40.00 & -13.3 & -10.9 & 4.7 & 5.9 & 0.0169 & 0.0164 & 0.0316 & 0.0189 & 4.6 & 4.5 & 3.84 & 3.82 & 1.210 & 1.176 & 72.9 & 82.0 & 88.3 & 98.7 \\
\hline 40.00 & -30.00 & -5.5 & -3.9 & 3.5 & 3.3 & 0.0256 & 0.0249 & 0.0479 & 0.0268 & 6.7 & 6.5 & 4.77 & 4.66 & 1.399 & 1.402 & 74.8 & 88.1 & 75.6 & 83.7 \\
\hline 40.00 & -35.00 & -8.8 & -6.9 & 3.8 & 4.2 & 0.0210 & 0.0200 & 0.0403 & 0.0221 & 5.6 & 5.4 & 4.52 & 4.41 & 1.238 & 1.213 & 77.2 & 94.0 & 82.2 & 92.9 \\
\hline 40.00 & -40.00 & -11.1 & -9.6 & 5.0 & 5.2 & 0.0164 & 0.0161 & 0.0323 & 0.0181 & 4.4 & 4.4 & 4.20 & 4.13 & 1.059 & 1.060 & 82.1 & 98.3 & 97.4 & 104.7 \\
\hline 50.00 & -30.00 & -2.2 & -2.1 & 3.9 & 3.1 & 0.0246 & 0.0243 & 0.0487 & 0.0287 & 6.2 & 6.3 & 5.33 & 5.09 & 1.163 & 1.239 & 86.6 & 98.2 & 88.8 & 89.6 \\
\hline 50.00 & -35.00 & -5.1 & -5.3 & 4.7 & 3.7 & 0.0197 & 0.0198 & 0.0416 & 0.0235 & 5.1 & 5.3 & 5.02 & 4.80 & 1.014 & 1.096 & 90.2 & 103.8 & 99.1 & 98.3 \\
\hline 50.00 & -40.00 & -8.4 & -7.6 & 5.3 & 4.8 & 0.0158 & 0.0157 & 0.0347 & 0.0185 & 4.2 & 4.2 & 4.65 & 4.48 & 0.900 & 0.939 & 91.9 & 109.9 & 109.5 & 112.6 \\
\hline
\end{tabular}

Table 6b. Data summary of the tests carried out at the compressors speeds: $N_{L}=1450 \mathrm{rpm}$ and $\mathrm{N}_{H}=1007 \mathrm{rpm}$ 